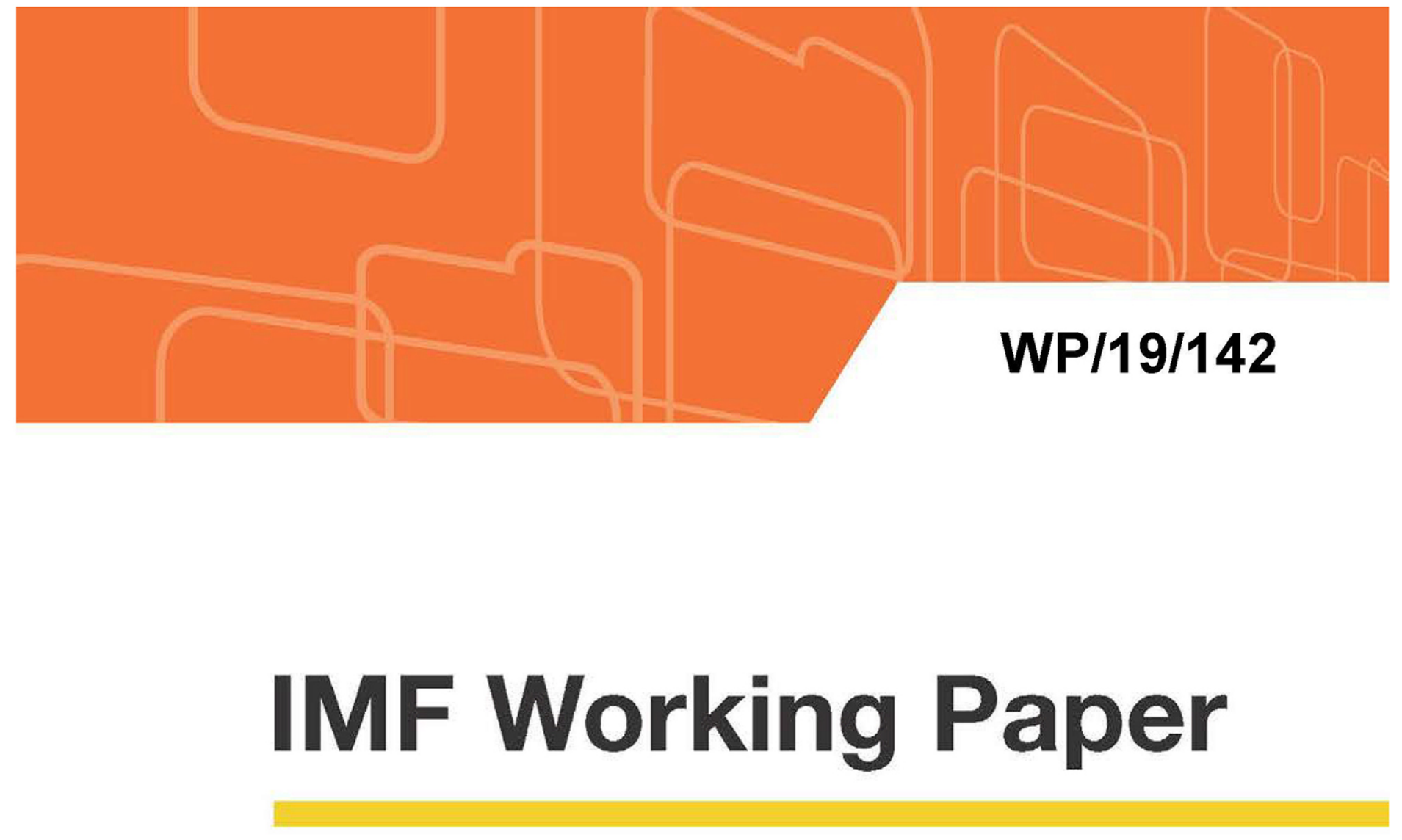

\title{
Technological Changes, Offshoring, and the Labor Share
}

by Weicheng Lian

IMF Working Papers describe research in progress by the author(s) and are published to elicit comments and to encourage debate. The views expressed in IMF Working Papers are those of the author(s) and do not necessarily represent the views of the IMF, its Executive Board, or IMF management. 


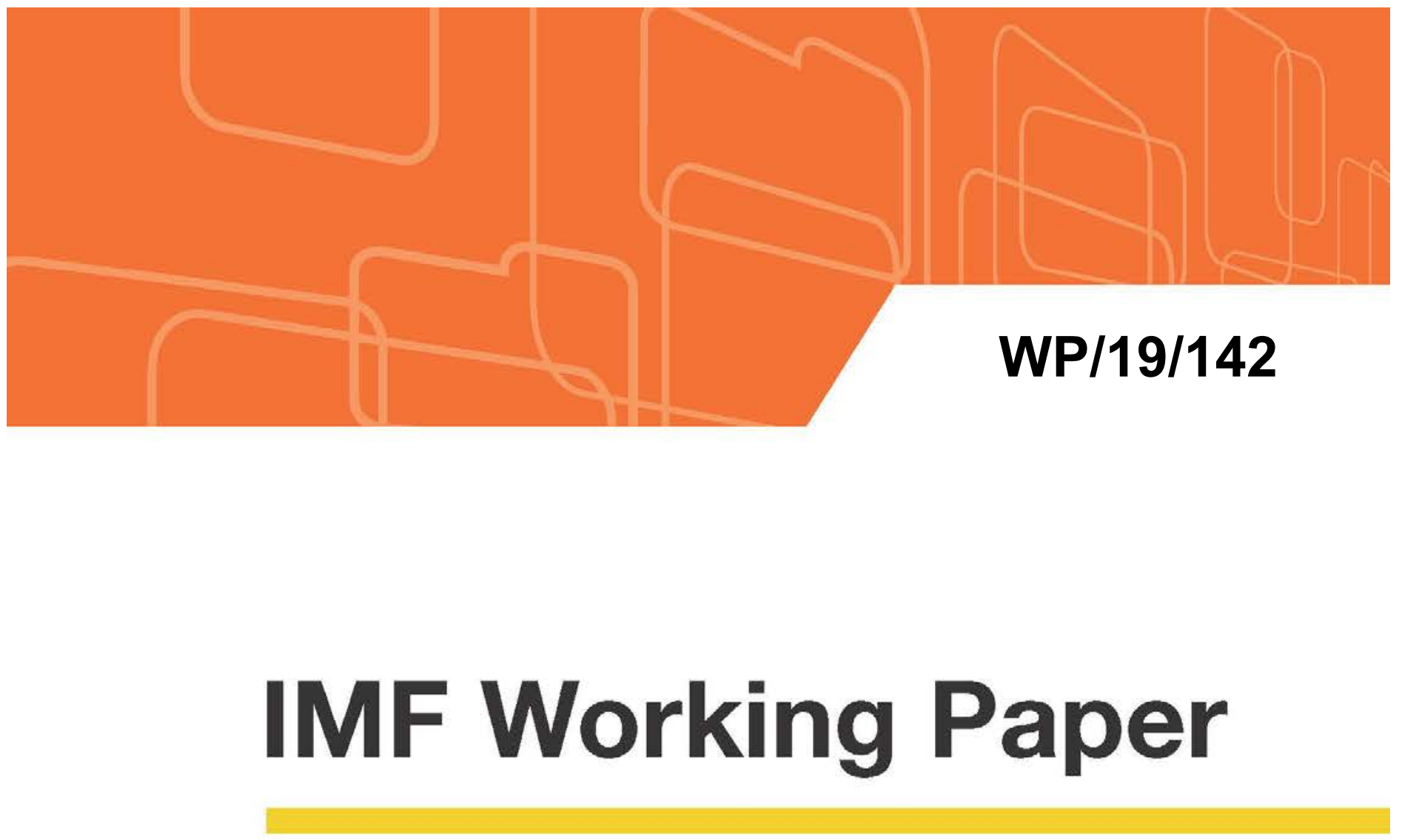

\title{
Technological Changes, Offshoring, and the Labor Share
}

\author{
by Weicheng Lian
}

IMF Working Papers describe research in progress by the author(s) and are published to elicit comments and to encourage debate. The views expressed in IMF Working Papers are those of the author(s) and do not necessarily represent the views of the IMF, its Executive Board, or IMF management. 


\title{
IMF Working Paper
}

Research Department

\section{Technological Changes, Offshoring, and the Labor Share \\ Prepared by Weicheng Lian}

Authorized for distribution by Oya Cealsun

July 2019

\section{IMF Working Papers describe research in progress by the author(s) and are published to elicit comments and to encourage debate. The views expressed in IMF Working Papers are those of the author(s) and do not necessarily represent the views of the IMF, its Executive Board, or IMF management.}

\begin{abstract}
Existing studies on the downward trend in the labor share of income mostly focus on changes within individual countries. I document, however, that half of the global decline in the labor share of income can be traced to the relocation of activities between countries. I develop a two-country model to show that when the relative price of investment goods falls, production activities with a small elasticity of substitution between capital and labor tend to get offshored from high- to low-wage countries. The model provides an explanation as to why such relocation may drive the labor share down in both developed and developing economies, as well as globally.

Keywords: Labor Share, Offshoring, Technological Changes, and Relative Cost of Capital Author's E-Mail Address: WLian@imf.org

JEL Codes: E23, E25, F11, F16, F21, F41, F62, F63, F66




\section{Introduction}

The global labor share of income declined by 4.9 percentage points between 1995 and $2007 .{ }^{1}$ The decline occurred not only in the United States but also in other countries, including developing countries such as China, Mexico, and Poland. ${ }^{2}$ While the commonality of the decline suggests that global forces such as technological change or trade integration may be the main drivers behind the trend, explanations based on a single one of these factors cannot match all of the relevant stylized facts. ${ }^{3}$

Technological change - a decline in the price of capital relative to the price of labor - can lower the labor share if the elasticity of substitution between capital and labor is greater than one. However, there is no consensus about the value of this elasticity. The vast majority of empirical studies estimate the elasticity of substitution to be smaller than 1 (Antras (2004), Oberfield and Raval (2014), Chirinko and Mallick (2017), and Raval (2019) among others). By contrast, using long time series data, Karabarbounis and Neiman (2013) finds patterns consistent with a value greater than $1 .^{4}$

The commonly-held view in the literature is that trade or offshoring may have strongly contributed to the decline in the labor share in some countries but not the decline in the global labor share. ${ }^{5}$ For instance, Neiman (2013) highlights that there is no theory that can explain why trade leads labor shares in both developed and developing countries - and the global economy -to decline simultaneously, and stresses the inability of the Heckscher-Ohlin theory to explain the decline in labor share in developing countries.

In this paper, I highlight an interaction between technological change and offshoring that helps

\footnotetext{
${ }^{1}$ The decline in global labor share is calculated for a balanced sample of countries using the corporate sector labor compensation and value-added compiled by Karabarbounis and Neiman (2013). I look at a balanced sample between 1995 and 2007, and use the IMF definition of advanced economies to classify countries into developed and developing countries throughout the paper. The appendix table A.1 lists the country names.

${ }^{2}$ See, for instance, Karabarbounis and Neiman (2013) and Dao et al. (2017)

${ }^{3}$ An incomplete list of studies examining labor shares includes Blanchard et al. (1997); Gollin (2002); Bentolila and Saint-Paul (2003); Atkinson (2009); Karabarbounis and Neiman (2013); Elsby, Hobijn and Şahin (2013); Bridgman et al. (2014); Oberfield and Raval (2014); Piketty and Zucman (2014); Koh, Santaeulàlia-Llopis and Zheng (2015); Lawrence (2015); Piketty (2015); Barkai (2016); Autor et al. (2017); Dao et al. (2017); Grossman et al. (2017); Hartman-Glaser, Lustig and Zhang (2017).

${ }^{4}$ The paper documents that countries with a stronger downward trend in relative price of investment goods also experienced a larger fall in labor share, suggesting that the elasticity of substitution between capital and labor is larger than 1.

${ }^{5}$ Elsby, Hobijn and Şahin (2013) documents that import competition significantly outperformed equipment prices in explaining different labor share trends across US industries. They also point out that the acceleration of the labor share decline during the 2000s in the United States did not coincide with a rise in capital stock to labor ratio.
} 
shed light on these issues. The main motivation for this focus comes from an empirical pattern documented by this paper that changes in the labor share in activities that stay within a country (the focus of most existing studies on the topic) contributed only around half of the decline in the global labor share between 1995 and 2007. The rest came from the relocation of economic activities from high-labor-share countries to low-labor-share countries. ${ }^{6}$ Likewise, I find that between-country shifts in activity are important in driving down global labor share for almost each of the manufacturing industries defined at the level 2 of the the International Standard Industrial Classification of all Economic Activities (ISIC) (using the World Input-Output database). ${ }^{7}$ The negative contribution of between-country shifts to the global labor share is an important stylized fact that requires an explanation.

This paper offers a theory of offshoring that can explain why labor share of income declines globally through declines in the labor share both within countries and through the relocation of activities from high- to low-labor share countries. Unlike what is predicted by the Heckscher-Ohlin theory, between-country shifts in activity emerge in the model in the context of smaller labor shares and faster growth in poorer countries. ${ }^{8}$ Importantly, a decline in the relative cost of capital causes the labor share to decline in both developed and developing countries in the model even if the average elasticity of substitution between capital and labor across firms in these economies is not greater than 1. This feature of the model implies that the economy-wide elasticity of substitution between capital and labor can be larger than the average elasticity of substitution across firms. The theory not only sheds light on a debate in the literature about whether offshoring can explain decline in labor share while being consistent with a broad set of facts related to labor share dynamics

\footnotetext{
${ }^{6}$ The contribution of within-country changes to the change in the global labor share is given by the weighted average of the changes in the corporate-sector labor share of individual countries, where the weight is the corporate sector value-added of the country in current dollar terms. I document this pattern using the labor share in the corporate sector, which was compiled by Karabarbounis and Neiman (2013). For tax purposes and by law, a corporation needs to report labor and capital income separately. Hence, using the corporate labor share is not subject to the notorious measurement issue one faces when determining the labor share at the national level given the difficulty in determining proprietors' labor income (Krueger (1999); Gollin (2002)).

${ }^{7}$ The only exception is the industry producing coke, refined petroleum product, and nuclear fuel.

${ }^{8}$ There are four labor share patterns in the data that are inconsistent with the Heckscher-Ohlin theory: first, there is a decline in global labor share, which is inconsistent with the theory in the benchmark case in which all production functions are Cobb-Douglas and consumption shares across goods are stable. As relative factor costs do not affect labor shares, the relocation of economic activities across borders should be a zero-sum for the global labor share. Second, the theory predicts that poorer countries specialize in more labor-intensive sectors and hence should have a higher labor share. In practice, however, the labor share (whether measured by corporate labor share or labor share in a given manufacturing industry) tends to be smaller in poorer countries. Third, the Heckscher-Ohlin theory cannot explain why labor share declines in developing countries, as highlighted by Neiman (2013). Finally, Karabarbounis and Neiman (2013) finds that within-industry changes dominate the decline in labor share at the national level.
} 
(Elsby, Hobijn and Şahin (2013); Neiman (2013)), but also on the puzzle about the value of the elasticity of substitution between capital and labor.

The key mechanism in the model rests on the specialization of poor countries in the production of goods for which the elasticity of substitution between capital and labor is smaller than 1. As the labor share in producing this type of goods is decreasing in the relative cost of capital, if the difference between rich and poor countries in the relative cost of capital is sufficiently large, such a specialization pattern can lead the labor share of poor countries to be smaller than that of rich countries. ${ }^{910}$ In this case, a relocation of activities with an elasticity of substitution that is less than one from rich to poor countries not only leads to a decline in global labor share, because labor share shrinks within the production of relocated goods, but also creates negative between-country effects. As I will explain shortly, this mechanism also leads labor share to decline within countries.

Why do poor countries specialize in the production of goods for which it is difficult to substitute capital for labor? The model in this paper generates this result through an interaction between technological change and offshoring. ${ }^{11}$ The mechanism goes as follows: a reduction of the relative price of investment goods raises the comparative advantage of poor countries in producing such goods (or equivalently, lowers their comparative advantage in producing goods for which it is easy to substitute capital for labor). In particular, a decline in the cost of capital relative to wages increases the labor cost share for "low elasticity of substitution" goods (regardless of which country produces them), so the labor-cost savings of relocating them from rich to poor countries increases. The opposite holds for those goods for which it is easy to substitute capital for labor: a decline in the relative price of investment goods strengthens the incentive to onshore them in rich countries and produce them more through capital.

The modeled world economy consists of two countries, north and south. The north is more productive than the south in producing all types of goods in a Hicks-neutral sense. Capital is mobile across borders, but labor can move only within countries. Cross-border relocation of production

\footnotetext{
${ }^{9}$ Previous studies document a negative correlation between the level of relative price of investment goods and the income level of countries (Hsieh and Klenow (2007); Lian et al. (2019)).

${ }^{10}$ Labor cost share is equal to $\frac{1}{1+\left(\frac{r}{w}\right)^{1-\rho} \frac{1-\alpha}{\alpha}}$, where $\frac{r}{w}$ is the relative cost of capital, $\rho$ is the elasticity of substitution between capital and labor, and $\alpha$ is labor intensity. Labor cost share decreases with $\frac{r}{w}$ if $\rho<1$.

${ }^{11}$ To map the mechanism to the real world, a plausible interpretation is that before the offshoring took off in the 1990s, technological change had substantially reduced the relative price of investment goods, causing automation of tasks. Therefore, once frictions for trade and offshoring are reduced, offshoring will be tilted towards goods for which the elasticity of substitution between capital and labor that is smaller than 1 due to the mechanism in the model.
} 
happens due to two types of drivers. The first type includes productivity convergence and different growth rates of labor force across countries, and triggers a relocation which goes in the same direction across goods with different elasticities of substitution between capital and labor. ${ }^{12} \mathrm{~A}$ decline in the relative price of investment goods is different from the first type of drivers in that it leads to relocation that goes in the opposite direction for activities with the elasticity of substitution larger versus smaller than 1. For simplicity, I assume that the two types of drivers offset each other in affecting goods for which the elasticity of substitution between capital and labor is larger than 1 in terms of the incentive of offshoring. This assumption also implies that the two types of forces reinforce each other and lead goods with smaller-than-1 elasticity of substitution between capital and labor to be relocated from the north to the south. Through the mechanism described above, the global labor share can decline due to relocation of activities across borders, which can further create negative between-country effects if the wage gap between the north and the south is sufficiently large.

The theory also explains why labor shares decline within countries. Elsby, Hobijn and Şahin (2013), a closely related paper, argues that a specialization of countries along the dimension of labor intensity can lead offshoring to drive down the labor share in both the north and the south, as cut-off goods (i.e. those goods for which firms are indifferent about where to produce) would be the most labor intensive in the north but the least labor intensive in the south. I find that an overlay of specialization along the dimension of the elasticity of substitution between capital and labor to the specialization along the dimension of labor intensity does not eliminate the mechanism highlighted by Elsby, Hobijn and Şahin (2013). In particular, I prove that cut-off goods whose elasticity of substitution between capital and labor is smaller than 1, i.e. those that are offshored from the north to the south, have the largest labor share in the north but the smallest labor share in the south. Therefore, the theory can explain not only why global labor share declines, and negative between-country effects emerge in the context of poorer countries having smaller labor share, but also why labor share declines in both rich and poor countries, consistent with the stylized facts presented in this paper. Thus, the proposed model is able to generate a rich set of empirical regularities simultaneously.

\footnotetext{
${ }^{12}$ Those offshoring drivers considered by previous studies (Feenstra and Hanson (1996); Grossman and RossiHansberg (2008)), including a decline in the trade or offshoring costs, also have this property.
} 
I present evidence supporting the mechanism by showing that industries with lower elasticity of substitution between capital and labor are indeed more exposed to offshoring, during a period with falling relative prices of investment goods. I show that exposure to offshoring can shed light on differences in the fall in labor share between industries with high versus low elasticity of substitution. I use industry-level estimates of the elasticity of substitution between capital and labor obtained by Oberfield and Raval (2014) and Raval (2019) to classify industries into high-, mediumand low-elasticity-of-substitution groups, and establish those patterns based on the NBER-CES manufacturing database and the World Input-Output database (WIOD) for the United States and the world economy respectively. ${ }^{13}$

As I will elaborate in the paper, the ability for offshoring to reduce labor share within a country is the key reason why the model can generate a large economy-wide elasticity of substitution between capital and labor as in Karabarbounis and Neiman (2013). The intuition is that a decline in the relative price of investment goods is not the only force causing the aggregate labor share to change, and offshoring drives up the economy-wide elasticity of substitution by creating cases in which the decline in labor share is strong but the decrease in relative cost of capital is mild, because offshoring or drivers of offshoring dampen the wage growth.

In a seminal paper, Gollin (2002) argues that smaller labor share in poorer countries is caused by a measurement issue; namely that poorer countries have a larger share of population being self-employed, and national accounts do not include the labor income of these people in labor compensation. While this may be a factor behind lower labor share at the national level recorded for developing countries compared with developed countries, it is not applicable to the labor share

\footnotetext{
${ }^{13}$ There are three patterns, with the first two for the United States based on the NBER-CES manufacturing database and the third for the world economy based on the WIOD. The first pattern is that industries with a smaller elasticity of substitution had experienced a stronger increase in the ratio of intermediate goods (excluding energy) to value-added since the $1980 \mathrm{~s}$, a period in which the relative price of investment goods fell. Secondly, the growth in the ratio of capital stock to employment accelerated in the 2000s. On the one hand, it cannot be attributed to the fall in relative prices of investment goods, which did not show any acceleration. On the other hand, it coincided with a faster rise in the ratio of intermediate goods to value-added and a sharper decline in employment. This pattern suggests that the faster pace of capital deepening was not caused by a substitution of capital for labor induced by changes in relative factor costs but by an offshoring of labor-intensive production. Interestingly, the labor share had declined faster in industries with higher elasticity of substitution before the 2000s, but more rapidly in those with lower elasticity of substitution during the 2000s. A plausible explanation is that the low-elasticity-of-substitution industries reduced its labor share more strongly through offshoring. Thirdly, industries with lowest elasticity of substitution experienced strongest rise in the ratio of intermediate goods to value-added in developed countries and largest decline in labor share in developing countries. Such patterns are consistent with the current theory's prediction that offshoring is the key force driving down labor share in developing countries, and the south specializes in goods with small elasticity of substitution between capital and labor.
} 
in the corporate sector that is the focus of the present study. ${ }^{14}$

This paper also relates to studies that examine the impact of technological change on labor markets and that highlight the role of capital-labor complementarity. Krusell et al. (2000) argues that an interaction between capital deepening and a stronger complementarity between higher skilled workers and capital can explain the rising skill premium. Autor and Dorn (2013) highlight that the polarization in the United States labor market was caused by automation of routine tasks due to falling costs of automation, as it has become cheaper to substitute capital for labor in routine tasks. Goos, Manning and Salomons (2014) highlights that it is difficult to separate the roles of automation and offshoring in the disappearance of routine tasks, which are not only easier to be automated but also more exposed to offshoring. A contribution of this paper is to reveal that declining relative prices of investment goods can lead to a displacement of routine jobs through both automation and offshoring - the elasticity of substitution between capital and labor is less essential and offshorability is more important than what is thought on the basis of previous studies.

The rest of the paper is organized as follows. Section 2 presents key stylized facts motivating the theory. Section 3 describes the theory. Section 4 provides evidence supporting the mechanism of the theory. Section 5 explores the wedge between macro and micro elasticity of substitution between capital and labor through a calibrated example. Section 6 discusses how the theory can shed light on the debates on the causes of downward trends in labor share. Section 7 concludes.

\section{Stylized Facts}

This section documents three empirical patterns related to the labor income share. First, through a shift share analysis, I show that the decline in the labor's share in global income was caused by not only a decline in labor share within countries but also a faster growth of countries with lower labor shares. Second, poorer countries have smaller labor share and faster growth. Third, labor shares did not show a sign of converge between rich and poor countries, despite strong trade integration. Notably, these patterns hold not only for the corporate sector but also for individual

\footnotetext{
${ }^{14}$ As argued by Armenter et al. (2015), "by law, corporations must declare payroll and profits separately for fiscal purposes, so there is actually no proprietor's income." Karabarbounis and Neiman (2013) also highlights that the corporate sector labor share is not subject to the measurement issue related to the self-employment: "As emphasized by Gollin (2002), aggregate labor share measures are influenced by the methods used to separate the labor and capital income earned by entrepreneurs, sole proprietors, and unincorporated businesses. The corporate labor share is not subject to such imputations."
} 
manufacturing industries.

I conduct shift-share analyses of the change of global labor share $(G L S)$ from $t_{0}$ to $t_{1}$ based on the following formula:

$$
\begin{aligned}
G L S_{t_{1}}-G L S_{t_{0}} & =\frac{\sum_{i} w_{i, t_{1}} L_{i, t_{1}}}{\sum_{i} V A_{i, t_{1}}}-\frac{\sum_{i} w_{i, t_{0}} L_{i, t_{0}}}{\sum_{i} V A_{i, t_{0}}} \\
& =\sum_{i} \theta_{i, t_{0}}\left(\frac{w_{i, t_{1}} L_{i, t_{1}}}{V A_{i, t_{1}}}-\frac{w_{i, t_{0}} L_{i, t_{0}}}{V A_{i, t_{0}}}\right)+\sum_{i}\left(\theta_{i, t_{1}}-\theta_{i, t_{0}}\right) \frac{w_{i, t_{1}} L_{i, t_{1}}}{V A_{i, t_{1}}}
\end{aligned}
$$

where $\theta_{i, t_{0}}=\frac{V A_{i, t_{1}}}{\sum_{j} V A_{j, t_{1}}}$ is the share of country $i$ in global value-added. $w, L$, and $V A$ denote wage, labor, and value-added respectively. The first term in the second row captures within-country changes in labor share, and the second term the contribution to changes in global labor share from a relocation of activities across countries with different level of labor share, which is referred to as between-country effects.

The formula can be further simplified, if we aggregate labor compensation and value-added of individual countries into those of two country groups (denoted as North and South):

$$
\sum_{g}\left(\theta_{g, t_{1}}-\theta_{g, t_{0}}\right) \frac{w_{g, t_{1}} L_{g, t_{1}}}{V A_{g, t_{1}}}=\left(\theta_{N, t_{1}}-\theta_{N, t_{0}}\right)\left(\frac{w_{N, t_{1}} L_{N, t_{1}}}{V A_{N, t_{1}}}-\frac{w_{S, t_{1}} L_{S, t_{1}}}{V A_{S, t_{1}}}\right) .
$$

Lemma 1 Negative between-country-group effects imply that: (i) $\theta_{N, t_{1}}>\theta_{N, t_{0}}$ and $\frac{w_{N, t_{1}} L_{N, t_{1}}}{V A_{N, t_{1}}}<$ $\frac{w_{S, t_{1}} L_{S, t_{1}}}{V A_{S, t_{1}}}$; or (ii) $\theta_{N, t_{1}}<\theta_{N, t_{0}}$ and $\frac{w_{N, t_{1}} L_{N, t_{1}}}{V A_{N, t_{1}}}>\frac{w_{S, t_{1}} L_{S, t_{1}}}{V A_{S, t_{1}}}$.

The main data source I use for the shift-share analysis is the KN Labor Share dataset (Karabarbounis and Neiman (2013)). It includes labor compensation and value-added of the corporate sector for 112 countries between 1975-2012. The sample is not balanced. To avoid the results being affected by the entry and exit of countries, I choose a balanced sample of 42 countries between 1995 and 2007 to conduct the analysis, and the Appendix Table A.1 lists their names, and their classification as developed and developing countries.

A key advantage of focusing on the labor share in the corporate sector rather than aggregate labor share measures (for example, total labor compensation divided by GDP) is that the crosscountry difference in the level of corporate labor share is unlikely to be driven by measurement issues (Krueger (1999); Gollin (2002)). Gollin (2002) argues that the reason that we observe smaller 
ratios of labor compensation to GDP in poorer countries is that the labor compensation in the national account does not include labor income of the self-employed, and a larger fraction of the population in poorer countries are self-employed. Without correcting this measurement error, a shift-share analysis is not meaningful. Fortunately, corporate labor share is not subject to the issue, and can be used to reveal the true cross-country effects in contributing to global labor share changes.

As a cross-checking for the patterns established using corporate labor shares, I explore labor share of individual manufacturing industries, based on the World Input-Output database (WIOD). As there is no evidence that poorer countries have more workers self-employed in manufacturing industries, the difference between developed and developing countries in manufacturing labor share is not necessarily caused by the self-employment issue identified by Gollin (2002).

Relocation of activities across countries seems to play an important role in causing global labor share to decline. Table 1 shows that around 44 to 64 percent of the global decline in labor share in the corporate sector between 1995 and 2007 was attributed to activities being shifted from highto low-labor-share countries, depending on whether the global financial crisis years are included in the sample period.

[Table 1 here]

The negative between-country effects were mainly caused by relocation of activities from developed to developing countries. Table 1 shows that between-country effects are very close to between-country-group effects, if I separate the sample into two groups, developed and developing countries. I define developed countries as advanced economies defined by the IMF October 2018 World Economic Outlook, and Appendix Table A.1 reports the country grouping. Moreover, between-country effects explained a small fraction of changes in labor share within the two country groups. Only 4 to 13 percent of the decline with a country group was caused by between-country effects.

What stood behind the negative between-country-group effects is that developing countries grew faster but had smaller labor share than developed countries - the case (ii) in Lemma 1. Figure 1 shows that the share of developing countries in global value-added of the corporate sector more than doubled between 1995-2007-it increased from 8.4\% in 1995 to $17.1 \%$ in 2007, and that labor share

CInternational Monetary Fund. Not for Redistribution 
was on average higher in developed countries than developing countries, by around 20 percentage points.

Interestingly, there was no sign of convergence in labor share between the two country groups, despite strong globalization and income convergence between developed and developing countries between 1995 and 2007. The gap increased from $18.3 \%$ in 1995 to $22.5 \%$ in 2007 . This pattern appears inconsistent with the prediction of the Heckscher-Ohlin theory that poorer countries tend to specialize in labor-intensive sectors. Trade integration should have led to a rise in labor share in developing countries, if production functions are Cobb-Douglass.

[Figure 1 here]

Between-country effects played a large role in affecting global labor share in the manufacturing sector. Cross-border shift in activities drove down global labor share between 1995 and 2007 in almost every manufacturing industries defined at the level 2 of the ISIC revision 3. Figure 2 shows this pattern for changes in payroll labor share between 1995 and 2007 using the WIOD. In several industries with mild decline in global labor share, such as food, wood, and rubber and plastic products, negative between-country effects dominated positive changes in labor share within countries. For industries with largest decline in global labor share, such as leather, basic metal, and transportation equipment, between-country effects accounted for around $1 / 3$ of the global decline. Figure 3 further suggests that labor share was substantially smaller in developing countries than developed countries, which holds for all manufacturing industries except for the one producing coke, nuclear fuels, and refined petroleum. The manufacturing activities expanded more in developing countries, with their share in global manufacturing value-added increasing substantially between 1995 and 2007.

[Figure 2 here]

[Figure 3 here]

The manufacturing labor shares in developed and developing countries both deviated from their earlier trends in the recent decade. Figure 4 shows that labor share ceased falling and even started to rise in developing countries, especially if China is included in the sample. As the deviation from 
the previous trend was stronger for developing countries (especially if China is included), there was some convergence in labor share between the two. However, the gap remained to be more than 20 percentage points in 2014 .

[Figure 4 here]

The pattern that labor share is smaller in poorer countries is unlikely to be caused by a difference in industry composition. The Orbis data set provides labor compensation and value-added at the firm level, which can be aggregated to industries defined at the level 4 of the NACE (Statistical Classification of Economic Activities in the European Community) revision 1. This enables a comparison of labor share across countries at a more granular level than what we have shown. Figure 5 shows that for the majority of the 4-digit industries, labor share was smaller in developing countries than deveoped countries, which does not depend on how we calculate the value-added at the firm level (turnover - material costs; value-added; compensation + EBITDA). In addition, the share of industries for which labor share in developing countries was smaller than that in developed countries had been broadly stable betwen 2000 and 2007, consistent with the idea that there was limited convergence in labor share between the two country groups.

[Figure 5 here]

\section{The Theory}

I develop a theory of offshoring and show that offshoring stands behind all three patterns documented in the previous section: negative between-country effects, lower labor share in poorer countries, and lack of convergence in labor share between rich and poor countries.

I develop the theory in two steps. In the first step, in a partial equilibrium setting, I consider Cobb-Douglass production functions as the benchmark and show that declining cost of capital does not affect offshoring decisions. Secondly, I relax the assumption about the production function and consider constant-elasticity-of-substitution (CES) production functions. I show that due to a fall in the cost of capital, offshoring can lead poorer countries to specialize in producing goods for which it is difficult to substitute capital for labor. 
Figure 6 illustrates the mechanism by plotting labor share of goods produced in the north and the south as a function of the elasticity of substitution between capital and labor in equilibrium. As goods with the same elasticity of substitution further differ from each other in labor intensity, the shaded areas in the top two panels capture the idea that due to specialization, the north produces relatively capital intensive goods and the south labor intensive goods.

[Figure 6 here]

A key element for creating the negative between-country effects is that labor share in the south should be smaller than that in the north. How does the mechanism generate it? Note that if due to a fall in relative price of investment goods, the south specializes in producing goods for which it is difficult to substitute capital for labor, the labor share in the south can be smaller than that in the north. Figure 6 shows that for the same cut-off good (i.e., those whose production cost is the same if their production is relocated across borders) with smaller-than-1 elasticity of substitution, its labor share in the north is larger than that in the south. This property is derived from another

property that the labor cost share of cut-off goods is decreasing (increasing) in the elasticity of substitution between capital and labor, if they are produced in the north (south). It will be proved in Proposition 4.

The mechanism generates a decline in global labor share, as the labor share shrinks within these cut-off goods. This can also explain why trade integration does not lead to a strong convergence in labor share between the north and the south.

Furthermore, the mechanism can create declines in labor share in both the north and the south through a shift in the composition of goods. As is illustrated in Figure 6, cut-off goods with small elasticity of substitution have largest labor share in the north and smallest labor share in the south. Labor shares in both countries decline when such cut-off goods are relocated from the north to the south.

\subsection{Cobb-Douglass Production Functions}

Consider a two-country model, which features a spectrum of goods that require different technology to produce. Throughout the paper, the production technology is exogenously determined for a given 
good, and the set of goods is unchanged for the global economy. The location of producing a specific good varies depending on the state of the global economy.

Production of goods requires both capital and labor. Capital is mobile across borders, and labor can move only within countries. What discourages goods production from being offshored from the north to the south is their difference in total factor productivity (TFP). The north has technological superiority over the south, and for simplicity, I assume that it is the same across all goods. Due to this TFP gap, the wage in the north is higher than that in the south. Only for goods for which the labor intensity exceeds a certain threshold, the wage gap dominates the TFP gap by making the south more attractive as a location of production.

For simplicity, I assume that the cost of shipping goods across borders is zero, and there are no other offshoring costs except fo the TFP gap. A TFP convergence can be seen as a short cut to capture a reduction in shipping costs or offshoring costs, as both encourage more goods to be offshored from the north to the south.

The consumer preference takes a logarithm form, so that the expenditure share of a good is constant. Oberfield and Raval (2014) considers a more general demand structure and does not find it to play a large role in explaining labor share dynamics in the manufacturing sector in the United States.

Production functions are Cobb-Douglass and differ from each other in labor intensity $\alpha$. Denote the unit cost of producing the good $\alpha$ as $C^{C D}(R, w ; \alpha)$, which is defined as follows:

$$
\begin{array}{r}
C^{C D}(R, w ; \alpha, A)=\min _{K, L}\{R K+w L\} \\
\text { s.t. } A K^{1-\alpha} L^{\alpha} \geq 1 .
\end{array}
$$

Through algebra, we can derive

$$
C^{C D}(R, w ; \alpha, A)=\frac{w^{\alpha} R^{1-\alpha}}{A \alpha^{\alpha}(1-\alpha)^{1-\alpha}} .
$$


Therefore, the set of goods produced in the south $\Lambda^{S}$ can be represented by

$$
\begin{aligned}
\Lambda^{S} & =\left\{\alpha: C^{C D}\left(R, w^{S} ; \alpha, A^{S}\right) \leq C^{C D}\left(R, w^{N} ; \alpha, A^{N}\right)\right\} \\
& =\left\{\alpha: \alpha \geq \frac{\log \left(\frac{A^{N}}{A^{S}}\right)}{\log \left(\frac{w^{N}}{w^{S}}\right)}\right\}
\end{aligned}
$$

which directly implies proposition 1.

Proposition 1 If production functions are Cobb-Douglass, the cost of capital $R$ does not affect offshoring decisions.

Define the cutoff goods as those whose unit production cost is unchanged if they are relocated. In the current case, they are goods whose labor intensity $\alpha$ satisfies

$$
\alpha=\frac{\log \left(\frac{A^{N}}{A^{S}}\right)}{\log \left(\frac{w^{N}}{w^{S}}\right)} .
$$

Proposition 2 If production functions are Cobb-Douglass, the global labor share is constant and the average labor share is larger in the south than the north. The cutoff goods are the most labor intensive in the north but the most capital intensive in the south.

Proof: a combination of the stability of expenditure share and the stability of labor share implies that the global labor share is constant. The rest of the proposition follows the characterization of set $\Lambda^{S}$. Q.E.D.

Elsby, Hobijn and Sahin (2003) uses the feature that cut-off goods are the most capital intensive among goods produced in the south but the most labor intensive among those in the north to argue that offshoring can lead to labor shares in the north and the south to decline simultaneously. I will extend this idea to a more general case with constant-elasticity-of-substitution (CES) production functions.

\subsection{CES Production Functions}

This subsection considers a more general case in which the production function is of a CES form. Technological difference between the north and the south is Hicks-neutral. I do not consider capitalaugmenting or labor-augmenting technological changes. Later, I will define macro elasticity of substitution between capital and labor as the amount of adjustment in the aggregate capital and 
labor for a given change in the relative cost of capital. There are two forces that affect this aggregate elasticity of substitution in this paper: (1) changes in the relative factor quantities used to produce a good; or (2) a shift in the composition of goods due to offshoring. This is in the same spirit of Oberfield and Raval (2014) who decompose aggregate elasticity of substitution into plant-level elasticity of substitution and relocation between capital- and labor-intensive plants. A key difference is that the shift in the composition of goods characterized by the current theory can occur within a plant.

Denote the cost of producing goods whose labor intensity is $\alpha$ and capital-labor elasticity of substitution is $\rho$ as $C^{C E S}(R, w ; \alpha, \rho)$, which satisfies

$$
\begin{aligned}
& C^{C E S}(R, w ; \alpha, \rho)=\min _{K, L}\{R K+w L\} \\
& \text { s.t. } \quad A\left((1-\alpha)^{\frac{1}{\rho}} K^{1-\frac{1}{\rho}}+\alpha^{\frac{1}{\rho}} L^{1-\frac{1}{\rho}}\right)^{\frac{\rho}{\rho-1}} \geq 1,
\end{aligned}
$$

from which we solve

$$
C^{C E S}(R, w ; \alpha, \rho, A)=\frac{\left(\alpha w^{1-\rho}+(1-\alpha) R^{1-\rho}\right)^{\frac{1}{1-\rho}}}{A}
$$

The set of goods produced in the south $\Lambda^{S}$ becomes:

$$
\begin{aligned}
\Lambda^{S} & =\left\{\alpha: C^{C E S}\left(R, w^{S} ; \alpha, \rho, A^{S}\right) \leq C^{C E S}\left(R, w^{N} ; \alpha, \rho, A^{N}\right)\right\} \\
& =\left\{(\alpha, \rho): \alpha \geq g\left(\rho ; \frac{A^{N}}{A^{S}}, w^{N}, w^{S}, R\right)\right\}, \\
\text { where } g(.) & =\frac{1}{1+\frac{\left(w^{N}\right)^{1-\rho}-\left(\left(\frac{A^{N}}{A^{S}} w^{S}\right)^{1-\rho}\right.}{R^{1-\rho}\left(\left(\frac{A^{N}}{A^{S}}\right)^{1-\rho}-1\right)}} .
\end{aligned}
$$

Proposition 3 Declining cost of capital leads cutoff goods with the elasticity of substitution between capital and labor that is smaller (larger) than 1 to be offshored from the north (south) to the south (north). Smaller productivity gap or larger wage gap between the north and the south encourages goods to be relocated from the north to the south (which does not depend on whether the elasticity of substitution between capital and labor is larger or smaller than 1).

Proof: the impact of the cost of capital on the direction of production relocation depends on 
whether $\rho$ is larger than 1 , because

$$
\begin{aligned}
& \frac{\partial g}{\partial R}<0 \text { if } \rho>1 \\
& \frac{\partial g}{\partial R}>0 \text { if } \rho<1 .
\end{aligned}
$$

The impact of other drivers on relocation is independent of whether $\rho$ is larger than 1 , and

$$
\frac{\partial g}{\partial\left(\frac{A^{N}}{A^{S}}\right)}>0 ; \frac{\partial g}{\partial w^{N}}<0 ; \frac{\partial g}{\partial w^{S}}<0
$$

Q.E.D.

For the first part of Proposition 3, there is a simple intuition: the net cost saving of relocating goods from the north to the south increases if the labor cost share rises. For goods for which the elasticity of substitution between capital and labor is smaller than 1, its labor cost share increases when the cost of capital declines relative to wage. It is the opposite for goods for which the elasticity of substitution is larger than 1. Mathematically, this intuition can be presented as:

$$
\frac{\partial^{2} \ln \left(C^{C E S}(R, w ; \alpha, \rho, A)\right)}{\partial R \partial w}=(1-\rho) \times M
$$

where $M$ is a positive term.

Proposition 4 The labor share of cut-off goods (i.e. those whose unit production cost is unchanged if relocated across borders) is decreasing (increasing) in the elasticity of substitution between capital and labor $\rho$ in the north (south).

Proof: see the appendix.

The intuition behind Proposition 4 is that the net cost saving of relocating production across borders depends on both the labor share and the elasticity of substitution between capital and labor, and the net cost saving being zero for the cut-off goods hence implies a relationship between the labor share and the elasticity of substitution between capital and labor for them. On the one hand, the labor share affects the net cost saving that comes from a change in the wage. For instance, for goods production that is relocated from the north to the south, the larger the labor share is, the greater the net cost saving that directly comes from a change in the wage is. On the other hand, the greater the elasticity of substitution is, the larger the net cost saving that comes 
from an adjustment of relative quantities is.

To see how such intuition implies the monotonic relationships characterized in Proposition 4 , for a cut-off good, suppose the optimal input bundle used to produce one unit of output changes from $\left\{L^{i}, K^{i}\right\}$ to $\left\{L^{j}, K^{j}\right\}$ if it is relocated from country $i$ to country $j$. As the unit production cost of cut-off goods is the same in both countries, $1=\frac{w^{j} L^{j}+R K^{j}}{w^{i} L^{i}+R K^{i}}$. We can hence decompose the right hand side of the equation further into two terms:

$$
\begin{aligned}
1 & =\frac{w^{j} L^{j}+R K^{j}}{w^{i} L^{i}+R K^{i}} \\
& =\frac{w^{j} L^{j}+R K^{j}}{w^{j} L^{i}+R K^{i}} \times \frac{w^{j} L^{i}+R K^{i}}{w^{i} L^{i}+R K^{i}} \\
& =\frac{w^{j} L^{j}+R K^{j}}{w^{j} L^{i}+R K^{i}} \times\left(1+\frac{w^{j}-w^{i}}{w^{i}} \times \frac{w^{i} L^{i}}{w^{i} L^{i}+R K^{i}}\right) .
\end{aligned}
$$

The first term $\frac{w^{j} L^{j}+R K^{j}}{w^{j} L^{i}+R K^{i}}$ captures changes in the quantities of capital and labor in response to changes in relative factor costs. As $\left\{L^{j}, K^{j}\right\}$ minimizes the production cost and $\left\{L^{i}, K^{i}\right\}$ does not, the first term is smaller if the elasticity of substitution between capital and labor is larger. The second term, $1+\frac{w^{j}-w^{i}}{w^{i}} \times \frac{w^{i} L^{i}}{w^{i} L^{i}+R K^{i}}$, depends on the labor share, $\frac{w^{i} L^{i}}{w^{i} L^{i}+R K^{i}}$, and the direction of the relocation (captured by $\frac{w^{j}-w^{i}}{w^{i}}$ ).

Now consider an example in which a cut-off good with relatively large elasticity of substitution between capital and labor is relocated from the south to the north. In this example, $i=S, j=N$ and $\frac{w^{j} L^{j}+R K^{j}}{w^{j} L^{i}+R K^{i}}$ is relatively small for this good. Given $\frac{w^{j}-w^{i}}{w^{i}}$ is positive, we infer that $\frac{w^{i} L^{i}}{w^{i} L^{i}+R K^{i}}$ should be relatively large for this good. It further implies that the labor share of cut-off goods is increasing in the elasticity of substitution between capital and labor in the south. If we consider a case in which cut-off goods are relocated from the north to the south, $\frac{w^{j}-w^{i}}{w^{i}}$ and the rest of the arguments above do not change. Hence the relationship between labor share and the elasticity of substitution turns from positive to negative for cut-off goods produced in the north.

Proposition 5 Cut-off goods for which the elasticity of substitution between capital and labor is smaller than 1 have largest labor share in the north but smallest labor share in the south.

Proof: This comes from a combination of two forces. First, cut-off goods are the most labor intensive in the north but the most capital intensive in the south conditional on the elasticity of substitution between capital and labor. Second, Proposition 4 gives the monotonic relationships 
between labor share and the elasticity of substitution. Q.E.D.

\subsection{Changes in Labor Shares}

This subsection studies how changes in factors that are exogenously given affect global labor share, and labor shares in the north and in the south. For simplicity, I make the following assumption to study how labor shares change.

Assumption 1 The cost of capital declines, and there are changes in other drivers of offshoring so that they offset each other in terms of the incentive to relocate the production across borders for goods for which the elasticity of substitution between capital and labor is greater than 1.

This assumption is broadly consistent with what the findings of Oberfield and Raval (2014) would imply. On the one hand, they show that the elasticity of substitution between capital and labor is smaller than 1 at both the plant and industry levels for all manufacturing industries. On the other hand, they argue that a change in technology such as automation may reduce aggregate labor share. The consistency between Assumption 1 and these findings is three-fold: (1) The elasticity of substitution between capital and labor of offshored goods is smaller than 1. (2) Goods that are previously produced in the north and further automated would stay in the north. (3) Some goods experience a decline in labor share due to a fall in the cost of capital/automation.

As drivers of offshoring other than the cost of capital trigger a relocation of production that goes in the same direction for goods with different elasticity of substitution between capital and labor, Assumption 1 implies that the fall in the relative cost of capital and other drivers of offshoring reinforce each other in causing goods for which the elasticity of substitution between capital and labor is smaller than 1 to be relocated from the north to the south.

To the extent that introducing goods with larger-than-1 elasticity of substitution captures labor or capital augmenting technological changes (rather than changes the relative efficiency of producing investment goods, which would be embedded in their relative prices) and if such technological changes (such as automation) occur more intensively in the north, I make assumption 2 to further simplify the analysis.

Assumption 2 Goods whose elasticity of substitution between capital and labor is larger than 1 are produced only in the North. 


\subsubsection{Between-Country Effects}

Proposition 6 suggests that if the wage gap between the north and the south is sufficiently large, the labor share in the south can be smaller than that in the north.

Proposition 6 Under assumption 2 and if $\mu\left(\Lambda^{o}\right)<1$, where

$$
\Lambda^{o}=\left\{(\alpha, \rho): \rho<1 \text { and } \alpha>\frac{1}{1+\frac{\left(w^{N}\right)^{1-\rho}}{\left.R^{1-\rho}\left(\left(1+\frac{A^{N}}{A^{S}}\right)\right)^{1-\rho}-1\right)}}\right\}
$$

there exists $\hat{w}$, such that if $w^{S}<\hat{w}$, the labor share in the south is smaller than that in the north.

Proof: The condition of the proposition ensures the labor intensity is sufficiently large so that some goods are produced in the south, and since its labor share declines with wage, the labor share goes to zero in the south when the wage converges to zero. Q.E.D.

Propostion 7 complements proposition 6 in highlighting that if the south specializes in producing goods with large elasticity of substitution between capital and labor, we will get the opposite from what the stylized fact suggests.

Proposition 7 If the elasticity of substitution between capital and labor is larger than 1 for all goods, the labor share in the south is larger than that in the north.

Proof: the south not only produces more labor intensive goods, and the labor share is an increasing function of the relative cost of capital if the elasticity of substitution between capital and labor is larger than 1. Q.E.D.

Building upon earlier results, Proposition 8 provides the conditions under which betweencountry effects can be negative in the current model.

Proposition 8 Under assumption 1 and 2 and if $\mu\left(\Lambda^{o}\right)<1$ and $w^{S}<\hat{w}$, with $\hat{w}$ defined in proposition 4, between-country effects are negative.

Proof: According to Lemma 1, negative between-country-group effects emerge if case (ii) holds, i.e., $\theta_{N, t 1}<\theta_{N, t 0}$ and $\frac{w_{N, t 1} L_{N, t 1}}{V A_{N, t 1}}>\frac{w_{S, t 1} L_{S, t 1}}{V A_{S, t 1}}$. Assumption 1 ensures that economic activities are relocated from the north to the south, which implies that $\theta_{N, t 1}<\theta_{N, t 0}$, and proposition 6 ensures that $\frac{w_{N, t 1} L_{N, t 1}}{V A_{N, t 1}}>\frac{w_{S, t 1} L_{S, t 1}}{V A_{S, t 1}}$. Q.E.D. 


\subsection{Within-Country Effects}

Offshoring leads labor share to decline in both the north and the south through a shift in the composition of goods, as the goods relocated from the north to the south have largest labor share in the north but smallest labor share in the south.

Proposition 9 Under assumption 1, offshoring leads labor share to decline in both the north and the south.

As an empirical support for the claim in proposition 9, Dao et al. (2017) shows that integration into global value chains reduces labor shares in both developed and developing countries.

\section{Micro Elasticity of Substitution and Changes in Labor Shares}

This section provides evidence supporting the mechanism of the theory, by showing that industries with lower elasticity of substitution between capital and labor are more exposed to offshoring, during a period with falling relative prices of investment goods. I further show that exposure to offshoring can shed light on differences in the fall in labor share between industries with high versus low elasticity of substitution.

I first classify manufacturing industries into three groups, based on the industry-level estimates of the elasticity of substation between capital and labor obtained by Oberfield and Raval (2014) and Raval (2019). In particular, for 19 manufacturing industries defined at the level 2 of the Standard Industrial Classification (SIC), Raval (2019) provides three sets of estimation results for each industry. I define industries with high elasticity of substitution as those with high point estimates and narrow standard error bands. In particular, I choose those ranked among the top four with the largest value of point estimate minus standard error at least twice in the three estimations. These industries are: food products (20), machinery (35), electrical machinery (36), and transportation equipment (37). Similarly, I define industries with low elasticity of substitution as those whose values of the sum of point estimate and standard error are ranked among the bottom four at least twice out of the three estimations. Four industries satisfy this criterion: furniture (25), paper (26), fabricated metal (34), and miscellaneous (39). The rest of the industries are then grouped into the medium-elasticity-of-substitution category.

I use "difference-in-difference (DID)" exercises to check whether there are structural breaks in 
the trends of relative factor quantities, relative factor prices, and factor shares, and argue that the patterns support the importance of offshoring in driving labor share. The analysis uses the NBERCES manufacturing database and the World Input-Output database (WIOD) to do the crossindustry-group comparison for the United States and the world economy respectively. The NBERCES database provides deflators of investment, capital stock, equipment capital stock, employment, the number of production workers, material costs, energy costs, labor compensation, and valueadded separately for 459 four-digit 1987 SIC industries in the United States between 1958-2011. The 2016 vintage of the WIOD provides intermediate inputs, total labor compensation and valueadded for 56 sectors and 43 countries between 2000-2014. I do not use the first vintage of the WIOD as it consolidates industries, which makes it not possible to create an accurate mapping into the industries whose elasticit of substitution between capital and labor is estimated by Raval (2019).

Before getting to the patterns that point to a role of offshoring in driving labor shares, I show that the long-run labor share trends are broadly consistent with the difference in elasticity of substitution between capital and labor across industry groups. Panel 1 of Figure 7 shows that the labor share had been larger in the high-elasticity group than the low-elasticity group, but the gap had sharnk between 1958-2011. Panel 2 and 3 of Figure 7 show that changes in the relative price of investment goods were broadly similar between the two groups, and the ratio of capital stock to employment rose more strongly in the long run in the high-elasticity group, especially after the 1980s, a period in which the relative price of investment goods fell.

\section{[Figure 7 here]}

There are three key patterns that suggest offshoring drives down labor share and the industry groups with lower elasticity of substitution are more exposed to offshoring. The first pattern is that industries with a smaller elasticity of substitution had experienced a stronger increase in the ratio of intermediate goods (excluding energy) to value-added since the 1980s, a period in which the relative price of investment goods fell (Panel 2 and 9, Figure 7 and 8).

[Figure 8 here]

Secondly, the growth in the ratio of capital stock to employment accelerated in the 2000s 
(Panel 3, Figure 7 and 8). On the one hand, it cannot be attributed to the fall in relative prices of investment goods, which did not show any acceleration (Panel 2, Figure 7 and 8). On the other hand, it coincided with a faster rise in the ratio of intermediate goods to value-added and a sharper decline in employment (Panel 6 and 9, Figure 7 and 8). This pattern suggests that the faster pace of capital deepening in the 2000s seen in Panel 3 of both figures was not caused by a substitution of capital for labor induced by faster decline in the relative cost of capital but by an offshoring of labor intensive production. Interestingly, the labor share had declined faster in industries with higher elasticity of substitution before the 2000s, but more rapidly in those with lower elasticity of substitution during the 2000s (Panel 1, Figure 7 and 8). These patterns support the claim that industries with smaller elasticity of substitution between capital and labor are more exposed to offshoring.

Thirdly, the pattern that offshoring activities in industries with lowest elasticity of substitution are more intense than those in other industries holds in general in developed countries. This force contributes to a fall in labor share in developing countries. Figure 9 and 10 show that industries with lowest elasticity of substitution experienced a strongest rise in the ratio of intermediate goods to value-added in developed countries and a largest decline in labor share in developing countries. Such patterns support the current theory's prediction that offshoring is the key force driving down labor share in developing countries, and the south specializes in goods with small elasticity of substitution between capital and labor. Table 2 further suggests that this pattern is not driven by a few large countries.

[Figure 9 here]

[Figure 10 here]

[Table 2 here]

\section{Macro vs. Micro Elasticity of Substitution Between Capital and Labor}

This section explores the difference between the macro elasticity of substitution between capital and labor and the average micro elasticity of substitution. I develop a general equilibrium model 
that incorporates the mechanism of the theory, and study how offshoring affects macro elasticity of substitution between capital and labor.

The design of the exercises is motivated by a debate regarding the value of the elasticity of substitution between capital and labor. Karabarbounis and Neiman (2013) estimates the elasticity of substitution to be greater than 1, while the vast majority of previous studies that estimate this parameter find its value to be smaller than 1. The key pattern based on which Karabarbounis and Neiman (2013) obtains the high value of the aggregate elasticity of substitution is that countries with a more rapid decline in labor share in the long run also experienced a stronger downward trend in the relative price of investment goods. They interpret the finding using a closed economy model with homogeneous elasticity of substitution between capital and labor.

The exercises in this section reveal that in a two-country model, there is a wedge between the macro elasticity of substitution and the average of micro elasticities of substitution, as drivers of offshoring affect wages and labor shares jointly. The macro elasticity of substitution between capital and labor can be large whenever the drivers of offshoring deepen the decline in the labor share but weaken the fall in the relative cost of capital by dampening wages.

To develop the general equilibrium model, I make factor costs endogenous but treat endowments of capital and labor exogenous. A representative household in country $k$ solves the following problem:

$$
\begin{array}{r}
\max \int \log c^{i, k}(\alpha, \rho) f(\alpha, \rho) d \alpha d \rho-\frac{\varphi^{k}}{1+\varphi^{k}}\left(\frac{L}{\bar{L}^{k}}\right)^{1+\frac{1}{\varphi^{k}}} \\
\text { s.t. } \int p(\alpha, \rho) c^{i, k}(\alpha, \rho) f(\alpha, \rho) d \alpha d \rho=K^{k}+w^{k} L^{k},
\end{array}
$$

where $K^{k}$ and $L^{k}$ are the initial endowments of capital and labor for households living in country $k$. For simplicity, the cost of capital $R$ is normalize to be 1 .

The wages $w^{N}$ and $w^{S}$ can be solved from two labor market clearing conditions:

$$
\begin{array}{r}
\int_{(\alpha, \rho) \in \Lambda^{k}} \frac{1}{1+\frac{1-\alpha}{\alpha} \frac{1}{w^{k}}{ }^{1-\rho}} \frac{\sum_{j \in\{H, L\}}\left(K^{j}+w^{j} \bar{L}^{j}\left(w^{j}\right)^{\varphi^{j}}\right.}{w^{k}} \\
\times f(\alpha, \rho) d \alpha d \rho=\bar{L}^{k}\left(w^{k}\right)^{\varphi^{k}} .
\end{array}
$$

It is worth noting that this general equilibrium model implies that due to capital mobility, 
the cross-country distribution of goods production depends on TFP difference rather than how the global endowment of capital is distributed across countries. However, the latter affects trade deficit. Large trade deficit emerges if there is a greater difference in the abundance of capital across countries.

The following proposition ensures that the equilibrium exists and is unique under certain conditions.

Proposition 10 There exist $\hat{\varphi}^{N}$ and $\hat{\varphi}^{S}$, such that if $\varphi^{N}>\hat{\varphi}^{N}$ and $\varphi^{S}>\hat{\varphi}^{S}$, there exists a unique equilibrium.

Proof: see appendix.

\subsection{Model Calibration}

To study the difference between macro and micro elasticity of substitution between capital and labor, I define the macro elasticity of substitution between capital and labor when the model economy changes from a state $S_{0}$ with the aggregate capital stock, aggregate employment, cost of capital and wage as $\left\{K_{0}, L_{0}, R_{0}, W_{0}\right\}$ to another state $S_{1}$ with $\left\{K_{1}, L_{1}, R_{1}, W_{1}\right\}$ as:

$$
\rho^{A g g}\left(S_{0}, S_{1}\right)=\frac{\log \left(\frac{K_{1}}{L_{1}}\right)-\log \left(\frac{K_{0}}{L_{0}}\right)}{\log \left(\frac{R_{1}}{W_{1}}\right)-\log \left(\frac{R_{0}}{W_{0}}\right)}
$$

In all the exercises below, I choose $S_{0}$ as the model economy calibrated to be consistent with the characteristics of the manufacturing sectors in 1995 in the world economy. I make a few simplifying assumptions. I normalize $L^{N}=1$ and $A^{S}=1$. I also set $\varphi^{N}=\varphi^{S}=0$, since numerical exercises suggest that there is a unique equilibrium under these parameters. I assume that the distribution of technology satisfies $\left[\alpha_{\min }, \alpha_{\max }\right] \times\left[0, \rho_{1}\right] \cup\left[\rho_{2}, \rho_{1}+\rho_{2}\right]$.

I choose a few parameters and calibrate the rest of the parameters to be consistent with certain targets. It is unlikely that the results are driven by the specific choices of these parameters. I choose the global capital stock to be 3 , and $\alpha_{\text {min }}=0.3$. I always impose Assumption 2 so that the model can create a sizable gap between the north and the south that is consistent with the data.

Five targets are used to determine the five parameters: $L^{S}, \alpha_{\max }, \rho_{1}, \rho_{2}$ and $A^{N}$ : (i) $\frac{L^{S}}{L^{N}}=2.24$; (ii) the labor share in the north is $60 \%$; (iii) that in the south is $41 \%$; (iv) the average elasticity of substitution between capital and labor is equal to 1 in the global economy when labor is mobile 
across borders; and $(\mathrm{v}) \frac{w^{N}}{w^{S}}=23$. These data targets are constructed using the WIOD. Target (i) is the ratio of the employment of middle-and-low skilled workers in the manufacturing industries in developing countries to that in developed countries. Targets (ii) and (iii) are the labor shares in manufacturing industries in developed and developing countries in 1995. The parameter choice satisifes the target (iv), and hence the quantitiative results in terms of why global labor share declines are driven by the mechanism of the current theory rather than through a substitution of capital for labor induced by cheaper capital (Karabarbounis and Neiman (2013)). ${ }^{15}$ Target (v) is the compensation per hour of a middle-and-low skilled worker in developed countries relative to that in developing countries in 1995. To match these targets, $\alpha_{\max }=0.7, \rho_{1}=0.65, \rho_{2}=1.18$, and $\frac{A^{N}}{A^{S}}=5.55$.

\subsection{Offshoring and Aggregate Elasticity of Substitution}

I construct three quantitative exercises in which drivers of offshoring lead the model economy to deviate from the state $S_{0}$, and calculate the implied aggregate elasticity of substitution using the definition in equation (1). There are three patterns. The first is that the model, despite its simplicity, can explain the decline in global labor share and labor shares in developed and developing countries for the manufacturing sector between 1995 and 2007 jointly and quantitatively very well. Secondly, a faster growth in the labor force size in developing countries relative to developed countries plays a quantitatively important role in driving down the global labor share and the labor share in the south during this period. Thirdly, the macro elasticity of substitution between capital and labor changes across exercises, implying a wedge between the macro and the micro elasticity of substitution that is endogenously determined by such drivers.

The three exercises are designed as follows. In the first exercise, I increase $L^{S}$ from 2.24 to 3.83 and keep $L^{N}$ unchanged, to mimic a faster increase in the labor force in developing countries relative to developed countries between 1995 and 2007, as the ratio of the employment of middleand-low skilled workers in the manufacturing industries in developing countries to that in developed countries increased from 2.24 in 1995 to 3.83 in 2007. In the next two exercises, in addition to the faster growth of labor force in the south, I consider an increase in global capital stock, or

\footnotetext{
${ }^{15}$ I ensure that target (iv) is achieved by assuming that there is no restriction in cross-border labor mobility and the model world economy becomes a closed economy in this case.
} 
productivity convergence so that more activities are relocated from the north to the south, to be consistent with what happened in practice. In the second exercise, $L^{S}$ increases from 2.24 to 3.83 , and the global capital stock grows from 3 to 5.5 so that the global labor share declines to its level in 2007 , which was $52 \%$. In the third one, $L^{S}$ inceases from 2.24 to 3.83 , and the productivity gap between the north and the south $\frac{A^{N}}{A^{S}}$ declines from 5.5 to 3.1 , so that the wage ratio $\frac{w^{N}}{w^{S}}$ shrinks from 23 to 15 , to be consistent with the change in the wage of middle-and-low skilled workers in developed countries relative to that in developing countries from 1995 to 2007.

The first exercise suggests that around half of the decline in global manufacturing labor share can be attributed to a rapid growth of employment in the manufacturing sector in developing countries, although this change may not be exogenous to other drivers of offshoring. What stands behind is a wage decline to encourage a strong relocation of activities from the north to the south to absorb the sizable increase in the labor force in the south. More specifically, Table 3 shows that with $L^{S}$ growing by $70 \%$, the north-south wage gap widened by $30 \%$. The ratio of the south wage to the north wage decreases from $\frac{1}{23}$ to $\frac{1}{33}$. This larger wage gap encourages more activities to be relocated from the north to the south, and the share of developing countries in global manufacturing value-added grows by $40 \%$, from $12 \%$ to $17 \%$.

[Table 3 here]

An increase in global capital stock, which captures a fall in the relative price of investment goods, and productivity convergence, which may capture a reduction in the cost of offshoring, can encourage a further relocation of activities from the north to the south and trigger wage convergence. It turns out that productivity convergence explains the data better than the increase in global capital stock, especially when it comes to explaining joint declines in global labor share and labor share in the south. The increase in global capital stock cannot achieve both quantitatively, but increases labor share in the south when I conduct the second exercise. In contrast, productivity convergence can generate declines in global labor share and labor shares in the north and the south that are very close to their data counterparts (meanwhile, matching the wage convergence, by design of the third exercise.)

The intuition is that a specialization of developing countries in goods for which it is difficult to substitute capital for labor creates two offsetting forces that drive the labor share in the south: an 
increase in wage relative to the cost of capital and receiving relatively capital intensive goods that are relocated from the north to the south. In the case of an increase in the global capital stock, the increase in the relative cost of labor dominates a shift in the composition of goods, and it is the opposite for productivity convergence. Table 3 shows two patterns that are consistent with this intuition. First, the increase in the global capital stock leads to a much weaker relocation of activities across borders, with the share of developing countries in global manufacturing value-added growing to $20 \%$ versus $28 \%$ in the case of the productivity convergence (the data counterpart is

$24 \%)$. Second, the share of the decline in global labor share attributed to negative between-country effects is substantially larger in the case of productivity convergence than the growth in global capital stock.

The aggregate elasticity of substitution between capital and labor is sensitive to the driver of offshoring. The aggregate elasticity of substitution in the north is 1.56 and 0.71 in the two exercises respectively, and the corresponding values in the south are 0.67 and 3.00.

Why is the value of this parameter so volatile? When does it go above 1? A common cause seems to be a mild decline in relative price of investment goods, but a significant decline in labor share, as is shown in Table 3. Offshoring plays a key role in making this possible. In the north, offshoring directly reduces demand for labor and dampens the wage growth. In the south, a strong increase in labor force helps reduce the wage growth but encourages stronger offshoring. A weaker wage growth contributes to a milder decline in the relative cost of capital.

\section{Discussion}

The theory sheds light on three issues related to the cause of the decline in labor share. First, what is the value of the elasticity of substitution between capital and labor? Second, what explains the decline in aggregate labor share? Is it between-firm relocation of activities or within-firm decline in labor share? Finally, does trade integration reduce aggregate labor share? The discussion in this section further explains the relationship between the theory of this paper and several previous studies in the labor share literature. 


\subsection{Elasticity of Substitution Between Capital and Labor}

As highlighted earlier, previous studies debate about the value of the elasticity of substitution between capital and labor, which matters for whether falling relative prices of investment goods directly lead to a decline in labor share.

A less recognized pattern is that the elasticity of substitution between capital and labor seems to be larger in developing countries than developed countries. There are two findings consistent with this claim. First, Oberfield and Raval (2014) finds that the elasticity of substitution is significantly larger in developing countries such as India, Colombia and Chile than in the United States. Second, Figure 11 separates the sample of Karabarbounis and Neiman (2013) into two sub-samples: developed countries and developing countries, and shows that the elasticity of substitution in developing countries seems to be larger than that in developed countries.

[Figure 11 here]

If there is no wedge between the macro elasticity of substitution and the average of micro elasticities of substitution between capital and labor, such patterns are puzzling. To my knowledge, there is no theory that explains why developing countries should specialize in goods for which it is relatively easy to substitute capital for labor - it is the opposite from the current theory's prediction.

This theory provides one possible explanation: offshoring can lead to a decline in labor share due to a shift in the composition of goods, and the decline in the relative cost of capital can be mild if offshoring is driven by falling costs of offshoring or barriers to trade and if a relocation of labor from non-tradable sectors to tradable sectors further dampens the wage increase. Interestingly, Dao et al. (2017) shows that the decline in the relative price of investment goods is indeed quite mild on average in developing countries. ${ }^{16}$

\subsection{Within- Versus Between-Firm Effects}

The shift in the composition of goods, a key element of the current mechanism to explain changes in labor share within a country, should happen within a firm-given the fact that firms make decisions regarding whether and where to offshore part of their production. As it is plausible that manufacturing industries are more exposed to offshoring than other sectors, the theory predicts

\footnotetext{
${ }^{16}$ See Figure 6 Panel 1 of Dao et al. (2017).
} 
that within-firm effects may be particularly negative in the manufacturing sector compared with other sectors.

This prediction is supported by Figure 10 of Autor et al. (2017), which is replicated in Figure 12. As their paper interprets the pattern as supporting a key role of between-firm effects in reducing aggregate labor share, the perspective provides by the current theory suggests that within-firm effects can also be crucial.

[Figure 12 here]

\subsection{Trade Integration and Labor Share}

The assumption that shipping costs are zero implies that offshoring captured by the theory is sharply different from the type of offshoring motivated by closer distance to final demands. Although I do not focus on trade flows, it is intuitive to argue that stronger offshoring induced by an incentive to reduce production costs should be associated with stronger trade integration. Therefore, we should see a link beteen trade integration and labor shares, if the theory is relevant for explaining changes in labor share in the real world.

I document three patterns that either support this claim or some key features of the mechanism. First, based on the WIOD, Table 4 shows that at the sector level, deeper trade integration leads to a sharper decline in labor share in manufacturing industries in developing countries. It is interesting to observe that such negative effects are robust if we separate exports and imports, although the overall effects seem to more come from exports. ${ }^{17}$ Second, using firm level data from the World Bank Enterprise Surveys (WBES) and the Orbis dataset, ${ }^{18}$ Table 5 and 6 show that foreign ownership is associated with lower labor share at the firm level in developing countries, and lower wages are associated with smaller labor shares. ${ }^{19}$

These patterns are consistent with a set of predictions of the theory. (i) Offshoring reduces labor

\footnotetext{
${ }^{17}$ This analysis uses 18 developing countries: Brazil, Bugaria, China, Croatia, Czech Republic, Estonia, Hungary, India, Indonesia, Latvia, Lithuania, Mexico, Poland, Romania, Russia, Slovak Republic, Slovenia, and Turkey. I merge the two vintage of the WIOD, and the sample period is $1995-2014$.

${ }^{18}$ For both datasets, I only look at manufacturing firms (the year of survey is in the paratheses.) I use data from the following WBES surveys: Brazil (2003,09); China(2012); India (2014); Indonesia (2009); Malyasia (2015); Mexico(2006,2010); Philippines(1995), Poland(2009, 2013);South Africa (2007); Thailand (2016); and Turkey (2008, 2013).

${ }^{19}$ Country-by-industry effects and country-by-year effects are controlled in the analysis of foreign-ownership-labor share link. Country, industry and year fixed effects are controlled in that of the wage-labor-share link.
} 
share in the south; (ii) Goods relocated from the north to the south are more capital intensive than those already produced in the south; (iii) An interaction between the relative cost of capital and a small elasticity of substitution between capital and labor can dominate specialization along the dimension of labor intensity to drive cross-country difference in labor share.

\section{Conclusion}

This paper documents that between-country effects play an important role in driving down global labor share, a pattern that can be established using either corporate labor share or labor share in individual manufacturing industries between 1995 and 2007. The Heckscher-Ohlin theory has difficulty in explaining the forces behind, namely labor share is smaller but growth is faster in poorer countries. It also more generally does not explain why global labor share declines.

I develop a theory that can generate between-country shifts in activity that lowers the labor share globally and in both high- and low-wage countries simultaneously. A key departure from existing theories is to consider a specialization of countries across goods with different elasticities of substitution between capital and labor, and to consider the relative price of investment goods as a driver of offshoring.

I show that after a decline in the relative price of investment goods, the incentive to further offshore goods for which it is easy to substitute capital for labor is weakened due to a strong substitution of capital for labor. In contrast, the resultant increase in the labor cost share for goods for which it is difficult to substitute capital for labor strengthens the incentive to produce them in low- rather than high-wage countries. Therefore, offshoring is tilted towards goods for which it is difficult to substitute capital for labor. The global labor share declines as the labor share shrinks within offshored goods. Moreover, when the wage gap between developed and developing countries is sufficiently large, the labor share can be smaller in developing versus developed countries, implying negative between-country effects.

I further show that the same mechanism can reduce labor share in both developed and developing countries, due to the property of relocated goods that they have the largest labor share in developed countries, but smallest labor share in developing ones. By making relocation of goods for which the elasticity of substitution between capital and labor is smaller than 1 active in driving down 
both global labor share and labor shares at the country level, the theory substantially weakens the role of the elasticity of substitution between capital and labor in the link between relative price of investment goods and labor share.

Indeed, a negative impact of offshoring on the labor share can lead the economy-wide elasticity of substitution between capital and labor to deviate from the average elasticity of substitution at the micro level. Using a calibrated general equilibrium two-country model, I show that the economy-wide elasticity of substitution between capital and labor can be quite volatile, influenced by offshoring. I argue that this theory sheds light on the debate about the value of the elasticity of substitution between capital and labor, especially the larger-than-1 elasticity of substitution found by Karabarbounis and Neiman (2013).

The theory provides a new perspective on the impact of technological change on labor markets, and implies a new within-firm adjustment mechanism, as offshoring is characterized as a response to declining relative prices of investment goods if it does not create a strong substitution of capital for labor, and such actions can take place within a multinational firm.

The theory also implies that offshorability is essential for the disappearance of routine jobs, and how easily a worker performing a routine job can be displaced by a machine is less critical in the labor-saving impact of technological advancement in high-wage countries, if it reduces the relative price of investment goods. 


\section{References}

Antras, Pol. 2004. "Is the US aggregate production function Cobb-Douglas? New estimates of the elasticity of substitution." Contributions in Macroeconomics, 4(1).

Armenter, Roc, et al. 2015. "A bit of a miracle no more: the decline of the labor share." Business Review $Q, 3: 1-9$.

Atkinson, Anthony B. 2009. "Factor shares: the principal problem of political economy?" Oxford Review of Economic Policy, 25(1): 3-16.

Autor, David, David Dorn, Lawrence F Katz, Christina Patterson, and John Van Reenen. 2017. "Concentrating on the Fall of the Labor Share." American Economic Review, 107(5): 180-85.

Autor, David H, and David Dorn. 2013. "The Growth of Low-Skill Service Jobs and the Polarization of the US Labor Market." The American Economic Review, 1553-1597.

Barkai, Simcha. 2016. "Declining labor and capital shares." Stigler Center for the Study of the Economy and the State New Working Paper Series, 2.

Bentolila, Samuel, and Gilles Saint-Paul. 2003. "Explaining movements in the labor share." Contributions in Macroeconomics, 3(1).

Blanchard, Olivier J, et al. 1997. "The medium run." Brookings Papers on Economic Activity, 89-141.

Bridgman, Benjamin, et al. 2014. Is Labor's Loss Capital's Gain?: Gross Versus Net Labor Shares. BEA.

Chirinko, Robert S, and Debdulal Mallick. 2017. "The substitution elasticity, factor shares, and the low-frequency panel model." American Economic Journal: Macroeconomics, 9(4): 22553.

Dao, Mai Chi, Ms Mitali Das, Zsoka Koczan, and Weicheng Lian. 2017. Why is labor receiving a smaller share of global income? Theory and empirical evidence. International Monetary Fund.

Elsby, Michael WL, Bart Hobijn, and Ayşegül Şahin. 2013. "The decline of the US labor share." Brookings Papers on Economic Activity, 2013(2): 1-63.

Feenstra, Robert C, and Gordon H Hanson. 1996. "Globalization, outsourcing, and wage inequality." National Bureau of Economic Research.

Gollin, Douglas. 2002. "Getting income shares right." Journal of political Economy, 110(2): 458474.

Goos, Maarten, Alan Manning, and Anna Salomons. 2014. "Explaining job polarization: Routine-biased technological change and offshoring." American Economic Review, 104(8): 250926.

Grossman, Gene M, and Esteban Rossi-Hansberg. 2008. "Trading tasks: A simple theory of offshoring." American Economic Review, 98(5): 1978-97.

Grossman, Gene M, Elhanan Helpman, Ezra Oberfield, and Thomas Sampson. 2017. "The productivity slowdown and the declining labor share: A neoclassical exploration." National Bureau of Economic Research.

Hartman-Glaser, Barney, Hanno N Lustig, and Mindy Xiaolan Zhang. 2017. "Capital Share Dynamics When Firms Insure Workers." Journal of Finance, Forthcoming, 16-35.

Hsieh, Chang-Tai, and Peter J Klenow. 2007. "Relative prices and relative prosperity." American Economic Review, 97(3): 562-585.

Karabarbounis, Loukas, and Brent Neiman. 2013. "The global decline of the labor share." The Quarterly journal of economics, 129(1): 61-103.

Koh, Dongya, Raül Santaeulàlia-Llopis, and Yu Zheng. 2015. "Labor share decline and the 
capitalization of intellectual property products."

Krueger, Alan B. 1999. "Measuring labor's share." American Economic Review, 89(2): 45-51.

Krusell, Per, Lee E Ohanian, José-Víctor Ríos-Rull, and Giovanni L Violante. 2000. "Capital-skill complementarity and inequality: A macroeconomic analysis." Econometrica, 68(5): 1029-1053.

Lawrence, Robert Z. 2015. "Recent declines in labor's share in US income: A preliminary neoclassical account." National Bureau of Economic Research.

Lian, Weicheng, Natalija Novta, Evgenia Pugacheva, Yannick Timmer, and Petia Topalova. 2019. "The price of capital goods: an investement driver under threat?" technical report.

Neiman, Brent. 2013. "Discussant comments on 'The Decline of the U.S. Labor Share' by Elsby, Hobijn, and Şahin."

Oberfield, Ezra, and Devesh Raval. 2014. "Micro Data and Macro Technology." NBER Working Paper, , (w20452).

Piketty, Thomas. 2015. "About capital in the twenty-first century." American Economic Review, 105(5): 48-53.

Piketty, Thomas, and Gabriel Zucman. 2014. "Capital is back: Wealth-income ratios in rich countries 1700-2010." The Quarterly Journal of Economics, 129(3): 1255-1310.

Raval, Devesh R. 2019. "The micro elasticity of substitution and non-neutral technology." The RAND Journal of Economics, 50(1): 147-167. 


\begin{tabular}{|c|c|c|c|c|c|c|}
\hline & $\begin{array}{l}\text { Overall } \\
\text { change }\end{array}$ & $\begin{array}{l}\text { Within } \\
\text { Country }\end{array}$ & $\begin{array}{l}\text { Between } \\
\text { Country }\end{array}$ & $\begin{array}{c}\text { Between } \\
\text { coun- } \\
\text { try/overall } \\
\text { change }\end{array}$ & $\begin{array}{c}\text { Within } \\
\text { Country } \\
\text { Group }\end{array}$ & $\begin{array}{c}\text { Between } \\
\text { Country } \\
\text { Group }\end{array}$ \\
\hline \multicolumn{7}{|c|}{ 1. All Countries } \\
\hline $1995-2007$ & $-4.9 \%$ & $-2.7 \%$ & $-2.1 \%$ & $44 \%$ & $-2.9 \%$ & $-2.0 \%$ \\
\hline $1995-2009$ & $-4.9 \%$ & $-1.8 \%$ & $-3.1 \%$ & $64 \%$ & $-2.0 \%$ & $-2.9 \%$ \\
\hline \multicolumn{7}{|c|}{ 2. $A E s$} \\
\hline $1995-2007$ & $-2.5 \%$ & $-2.4 \%$ & $-0.1 \%$ & $4 \%$ & & \\
\hline $1995-2009$ & $-1.6 \%$ & $-1.4 \%$ & $-0.2 \%$ & $11 \%$ & & \\
\hline \multicolumn{7}{|c|}{ 3. EMDEs } \\
\hline $1995-2007$ & $-6.7 \%$ & $-5.9 \%$ & $-0.8 \%$ & $12 \%$ & & \\
\hline $1995-2009$ & $-6.3 \%$ & $-5.5 \%$ & $-0.8 \%$ & $13 \%$ & & \\
\hline
\end{tabular}

Table 1: Shift-Share Decomposition of Global Decline in Corporate Labor Share

Sources: KN Labor Share Dataset; and the author's calculations.

Note: The Appendix Table A.1 lists the sample countries. 


\begin{tabular}{|c|c|c|c|c|c|c|}
\hline \multirow[b]{3}{*}{ VARIABLES } & \multicolumn{6}{|c|}{ A. $100 \times \log ($ labor share $)$} \\
\hline & \multicolumn{3}{|c|}{ Developed countries } & \multicolumn{3}{|c|}{ Developing countries } \\
\hline & High EOS & Medium EOS & Low EOS & High EOS & Medium EOS & Low EOS \\
\hline Year & $\begin{array}{c}0.191 \\
(0.157)\end{array}$ & $\begin{array}{c}0.116^{*} \\
(0.058)\end{array}$ & $\begin{array}{c}0.166 \\
(0.228)\end{array}$ & $\begin{array}{c}-0.479^{*} \\
(0.253)\end{array}$ & $\begin{array}{c}0.030 \\
(0.084)\end{array}$ & $\begin{array}{c}-0.570^{*} \\
(0.277)\end{array}$ \\
\hline Observations & 372 & 372 & 372 & 132 & 132 & 132 \\
\hline \multirow[t]{3}{*}{ R-squared } & 0.855 & 0.921 & 0.677 & 0.912 & 0.980 & 0.881 \\
\hline & \multicolumn{6}{|c|}{ B. $100 \times \log ($ intermediate goods/value-added $)$} \\
\hline & \multicolumn{3}{|c|}{ Developed countries } & \multicolumn{3}{|c|}{ Developing countries } \\
\hline VARIABLES & High EOS & Medium EOS & Low EOS & High EOS & Medium EOS & Low EOS \\
\hline Year & $\begin{array}{c}0.634^{* *} \\
(0.301)\end{array}$ & $\begin{array}{c}0.810^{* * *} \\
(0.278)\end{array}$ & $\begin{array}{c}2.077^{* * *} \\
(0.467)\end{array}$ & $\begin{array}{c}0.530 \\
(0.547)\end{array}$ & $\begin{array}{c}0.523^{*} \\
(0.238)\end{array}$ & $\begin{array}{c}0.809 \\
(0.495)\end{array}$ \\
\hline Observations & 372 & 372 & 372 & 132 & 132 & 132 \\
\hline R-squared & 0.871 & 0.915 & 0.813 & 0.940 & 0.975 & 0.624 \\
\hline
\end{tabular}

Table 2: Trends of Labor Share and Intermediate Goods-to-Vaue-Added Ratio

Sources: the World Input-Output database (WIOD); and the author's calculations.

Note: Country and year fixed effects are both controlled for in all regressions. To avoid the results being driven by the United States, the AE group excludes the US. But the pattern is robust to including the United States. 


\begin{tabular}{|c|c|c|c|c|c|c|}
\hline & Data in 1995 & Data in 2007 & Model state $S_{0}$ & $\Delta L$ & $\Delta L$ and $\Delta K$ & $\Delta L$ and $\Delta A$ \\
\hline $\begin{array}{l}\text { Manufacturing labor } \\
\text { share in the north }\end{array}$ & $60 \%$ & $57 \%$ & $59 \%$ & $59 \%$ & $54 \%$ & $57 \%$ \\
\hline $\begin{array}{l}\text { Manufacturing labor } \\
\text { share in the south }\end{array}$ & $41 \%$ & $36 \%$ & $40 \%$ & $34 \%$ & $45 \%$ & $37 \%$ \\
\hline $\begin{array}{l}\text { Global manufacturing } \\
\text { labor share }\end{array}$ & $58 \%$ & $52 \%$ & $57 \%$ & $54 \%$ & $52 \%$ & $51 \%$ \\
\hline $\begin{array}{l}\text { Share of developing } \\
\text { countries in global } \\
\text { manufacturing value-added }\end{array}$ & $11 \%$ & $24 \%$ & $12 \%$ & $17 \%$ & $20 \%$ & $28 \%$ \\
\hline $\begin{array}{l}\text { Relative cost of capital } \\
\text { in the north }\end{array}$ & & & 0.28 & 0.31 & 0.2 & 0.4 \\
\hline $\begin{array}{l}\text { Relative cost of capital } \\
\text { in the south }\end{array}$ & & & 6.67 & 10 & 3.8 & 6.25 \\
\hline $\begin{array}{l}\text { Wage in the north/ } \\
\text { wage in the south }\end{array}$ & 23 & 15 & 23 & 33 & 19 & 15 \\
\hline $\begin{array}{l}\text { Decline in global labor share } \\
\text { Within country changes } \\
\text { Between country changes }\end{array}$ & & & & $\begin{array}{l}2.3 \% \\
1.2 \% \\
1.1 \% \\
\end{array}$ & $\begin{array}{l}4.3 \% \\
3.6 \% \\
0.7 \% \\
\end{array}$ & $\begin{array}{l}5.6 \% \\
2.6 \% \\
3.0 \% \\
\end{array}$ \\
\hline $\begin{array}{l}\text { Implied aggregate elasticity } \\
\text { of substitution in the north }\end{array}$ & & & & 0.85 & 1.56 & 0.71 \\
\hline $\begin{array}{l}\text { Implied aggregate elasticity } \\
\text { of substitution in the south }\end{array}$ & & & & 0.37 & 0.67 & 3.00 \\
\hline
\end{tabular}

Table 3: Calibrated Example: Model Outcomes Under Different Offshoring Drivers

Sources: The author's calculations.

Note: The table reports the model outcomes under different changes in drivers of offshoring. 


\begin{tabular}{|c|c|c|c|c|c|}
\hline VARIABLES & $\begin{array}{c}(1) \\
\text { Baseline }\end{array}$ & $\begin{array}{c}(2) \\
\text { Separate } \\
\text { exports and } \\
\text { imports }\end{array}$ & $\begin{array}{c}(3) \\
\text { Before } 2007\end{array}$ & $\begin{array}{l}\quad \quad(4) \\
\text { Exclude } \\
10 \% \\
\text { extreme } \\
\text { values }\end{array}$ & $\begin{array}{l}\quad(5) \\
\text { Change } \\
\text { definition } \\
\text { of } \\
\text { developing } \\
\text { countries }\end{array}$ \\
\hline$\Delta \log ($ total trade $)$ & $\begin{array}{c}-0.114^{* * * *} \\
(0.025)\end{array}$ & & $\begin{array}{c}-0.137^{* * * *} \\
(0.044)\end{array}$ & $\begin{array}{c}-0.058^{* * *} \\
(0.009)\end{array}$ & $\begin{array}{c}-0.101^{* * *} \\
(0.033)\end{array}$ \\
\hline$\Delta \log ($ exports $)$ & & $\begin{array}{c}-0.071^{* *} \\
(0.029)\end{array}$ & & & \\
\hline$\Delta \log ($ imports $)$ & & $\begin{array}{l}-0.041 \\
(0.039)\end{array}$ & & & \\
\hline Observations & 4,044 & 4,041 & 2,532 & 4,044 & 2,676 \\
\hline R-squared & 0.107 & 0.108 & 0.100 & 0.374 & 0.101 \\
\hline
\end{tabular}

Standards are clustered at the country by sector level.

$* * * \mathrm{p}<0.01, * * \mathrm{p}<0.05, * \mathrm{p}<0.1$

Table 4: Trade Integration and Labor Share Changes in Manufacturing Industries in Developing Countries

Sources: The World Input-Output database (WIOD); and the author's calculations.

Note: The dependent variable is change in payroll labor share from last year. Country by year fixed effects are controlled for in all specifications. Column (4) winsorize both change in labor share and change in total trade at 10\% level. Column (5) differ from column (1) by excluding Czech Republic, Lativa, Lithuania, Estonia, Slovak Republic, and Slovenia, which are defined by the October 2018 World Economic Outlook Reports as advanced economies. See the Appendix for the definition of variables, and the Appendix Table A.1 for the list of countries. 


\begin{tabular}{lcccc}
\hline VARIABLES & $\begin{array}{c}(1) \\
\text { Baseline }\end{array}$ & $\begin{array}{c}(2) \\
\text { Before } 2007\end{array}$ & $\begin{array}{c}(3) \\
\text { Excluding China }\end{array}$ & $\begin{array}{c}(4) \\
\text { Excluding all } \\
\text { Asian coun- } \\
\text { tries }\end{array}$ \\
\hline $\begin{array}{l}\text { Foreign share larger } \\
\text { than } 10 \%\end{array}$ & $-6.766^{* * *}$ & $-3.511^{* *}$ & $-7.311^{* * *}$ & $-5.318^{* * *}$ \\
& $(0.995)$ & $(1.535)$ & $(1.066)$ & $(1.312)$ \\
Observations & 17,155 & 2,973 & 15,764 & 7,308 \\
R-squared & 0.137 & 0.160 & 0.137 & 0.150 \\
\hline
\end{tabular}

The standard errors are clustered at the country by sector level.

$* * * \mathrm{p}<0.01, * * \mathrm{p}<0.05, * \mathrm{p}<0.1$

Table 5: Foreign Ownership and Labor Shares in Manufacturing Industries in Developing Countries

Sources: The World Bank Enterprise Surveys; and the author's calculations.

Note: Note: The dependent variable is labor share. Country by sector fixed effects and country by year fixed effects are controlled for in all specifications. See the Appendix for the definition of variables, and the Appendix Table A.1 for the list of countries. 


\begin{tabular}{lcc}
\hline & $(1)$ & $(2)$ \\
VARIABLES & Labor share & Labor share \\
\hline Log(wage) & $0.124^{* * *}$ & $0.124^{* * *}$ \\
& $(0.0282)$ & $(0.0177)$ \\
4-digit industry fixed effects & $\mathrm{Y}$ & $\mathrm{Y}$ \\
Country fixed effects & $\mathrm{N}$ & $\mathrm{Y}$ \\
Year fixed effects & $\mathrm{Y}$ & $\mathrm{Y}$ \\
Constant & 0.314 & 0.0719 \\
& $(0.310)$ & $(0.224)$ \\
Clustering at the country level & $\mathrm{Y}$ & $\mathrm{Y}$ \\
& & 18,704 \\
Observations & 18,704 & 0.471 \\
R-squared & 0.342 & \\
\hline
\end{tabular}

Standard errors are clustered at the country by sector level.

*** $p<0.01,{ }^{* *} p<0.05,{ }^{*} p<0.1$

Table 6: Wages and Labor Shares at the Firm Level

Sources: Orbis; and the author's calculations.

Note: The dependent variable is labor share. Country by sector fixed effects and country by year fixed effects are controlled for in all specifications. 


\section{Labor Share by Country Group}

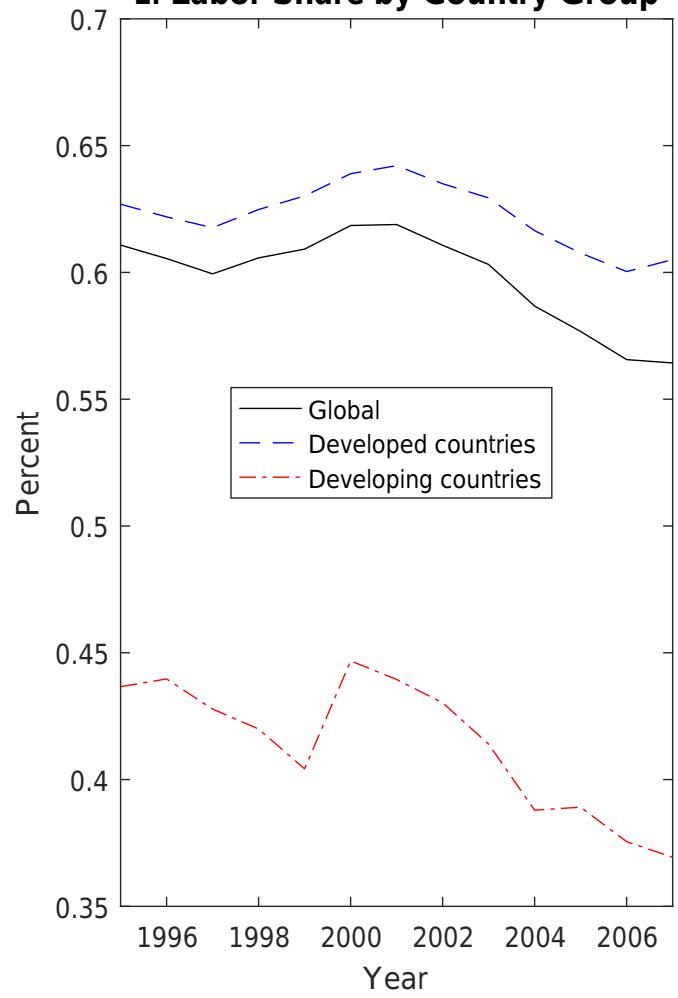

\section{Developing Corporate Value-added Share}

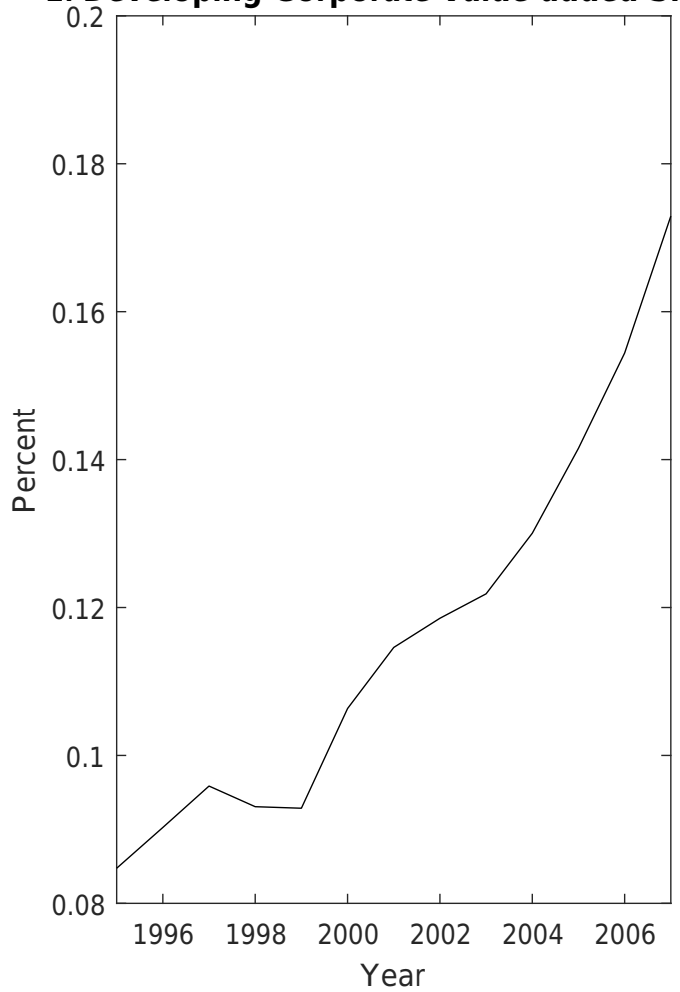

Figure 1: Labor Income Shares and Developing Countries' Share in the Global Value-Added of the Corporate Sector

Sources: Karabarbounis and Neiman (2013); The KN Labor Share dataset; and the author's calculations.

Note: This figure suggests that negative between-country effects come from the fact that developing countries had smaller labor share and grew faster than developed countries. It is important to recognize that corporate labor share is not subject to the measurement issue identified by Gollin (2002) (aggregate labor share is biased downward as it does not include the labor income of the self-employed, and this bias is larger for developing countries, as a larger fraction of work force is self-employed there.). See the Appendix Table A.1 for the list of countries. 


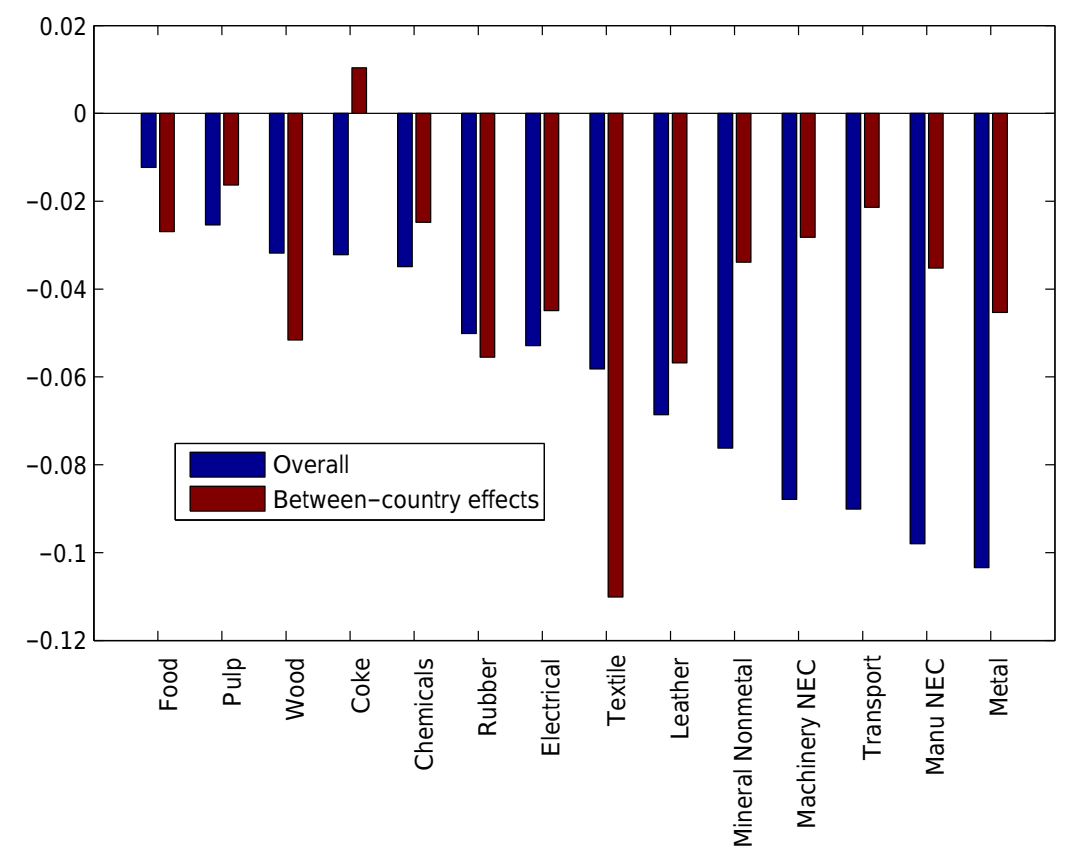

Figure 2: Decline in the Labor's Share in Global Value-Added by Manufacturing Industry: Overall and Between-Country Effects

Sources: The World Input-Output database (WIOD); and the author's calculations.

Note: This figure shows that between-country effects played a large role in the decline in global manufacturing labor share. It is useful to recognize that there is no strong evidence that developing countries have a larger fraction of the labor force being self-employed than developed countries, when it comes to the employment in manufacturing industries. See the Appendix Table A.1 for the list of countries. 

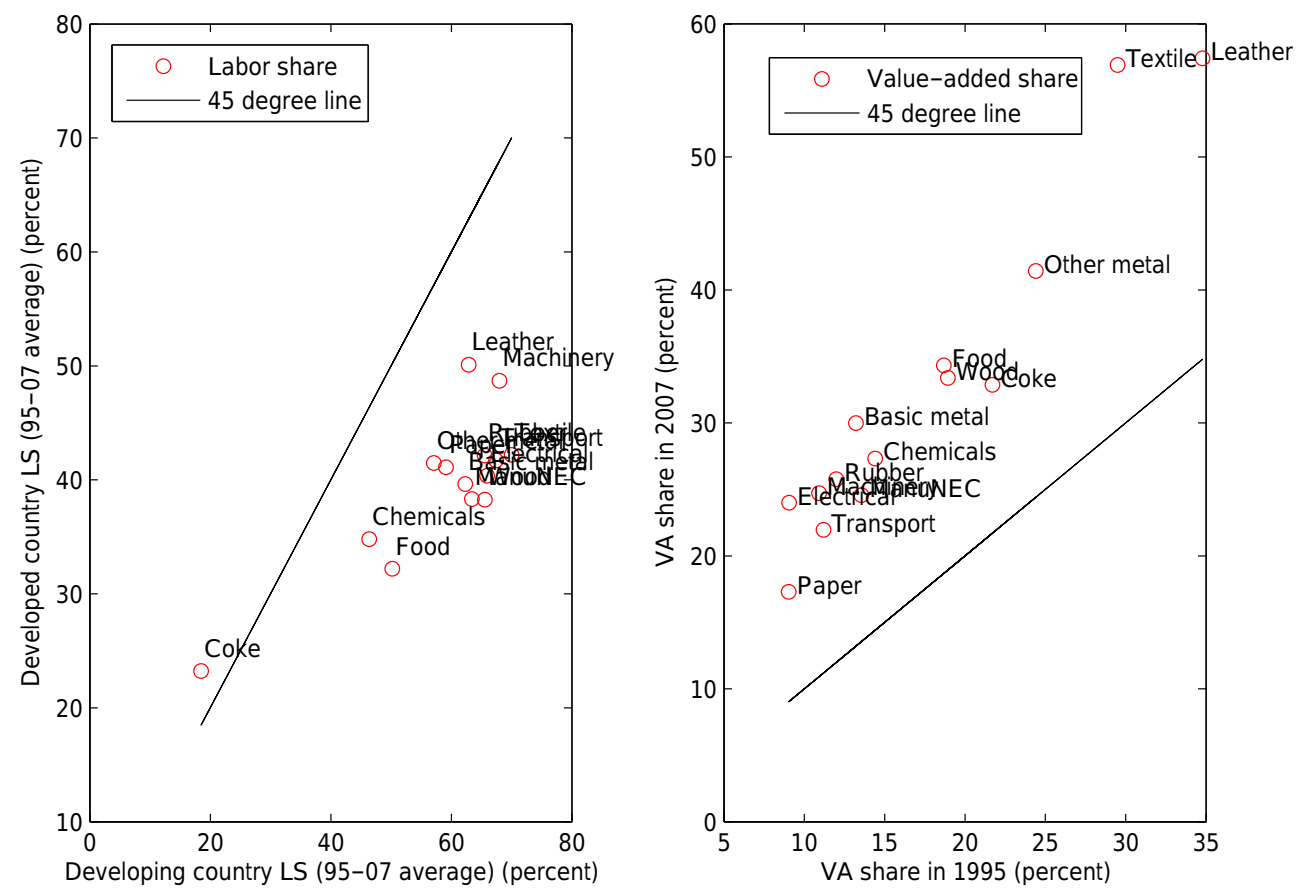

Figure 3: Labor Share by Country Group and Developing Countries' Share in Global Manufacturing ValueAdded

Sources: the World Input-Output database (WIOD); and the author's calculations.

Note: LS = Labor share; VA share: developing countries' share in global value-added of manufacturing industries. This figure shows that between-country effects played a large role in the decline in global manufacturing labor share. See the Appendix Table A.1 for the list of countries. 

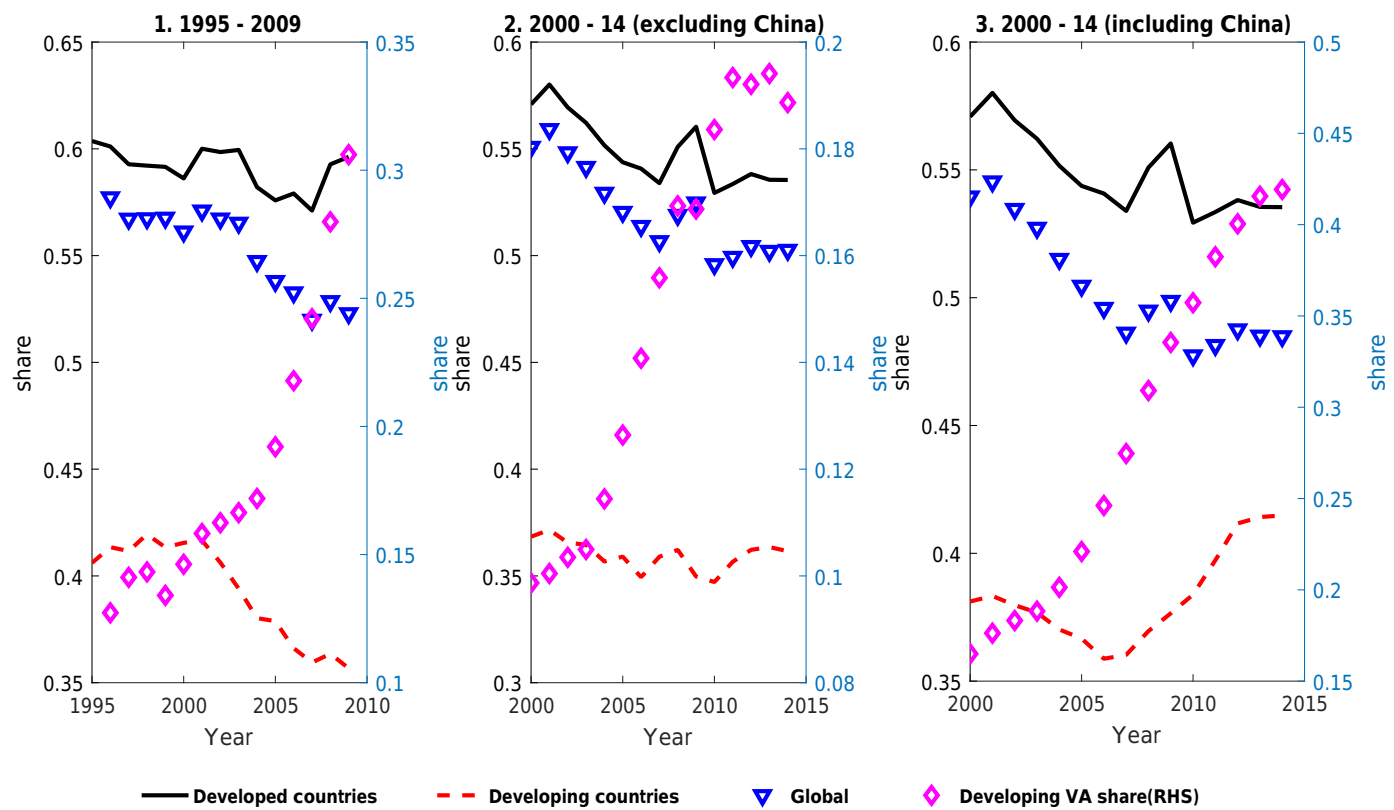

Figure 4: Manufacturing Labor Share by Country Group: 1995 - 2014

Sources: The World Input-Output database (WIOD); the author's calculations.

Note: This figure shows changes in the labor share in the manufacturing sector for developed and developing countries between 1995 and 2014. The WIOD has two vintages, covering the period between 1995-2009 and that between 2000-14 respectively. The Appendix Table A.1 lists the sample countries. 


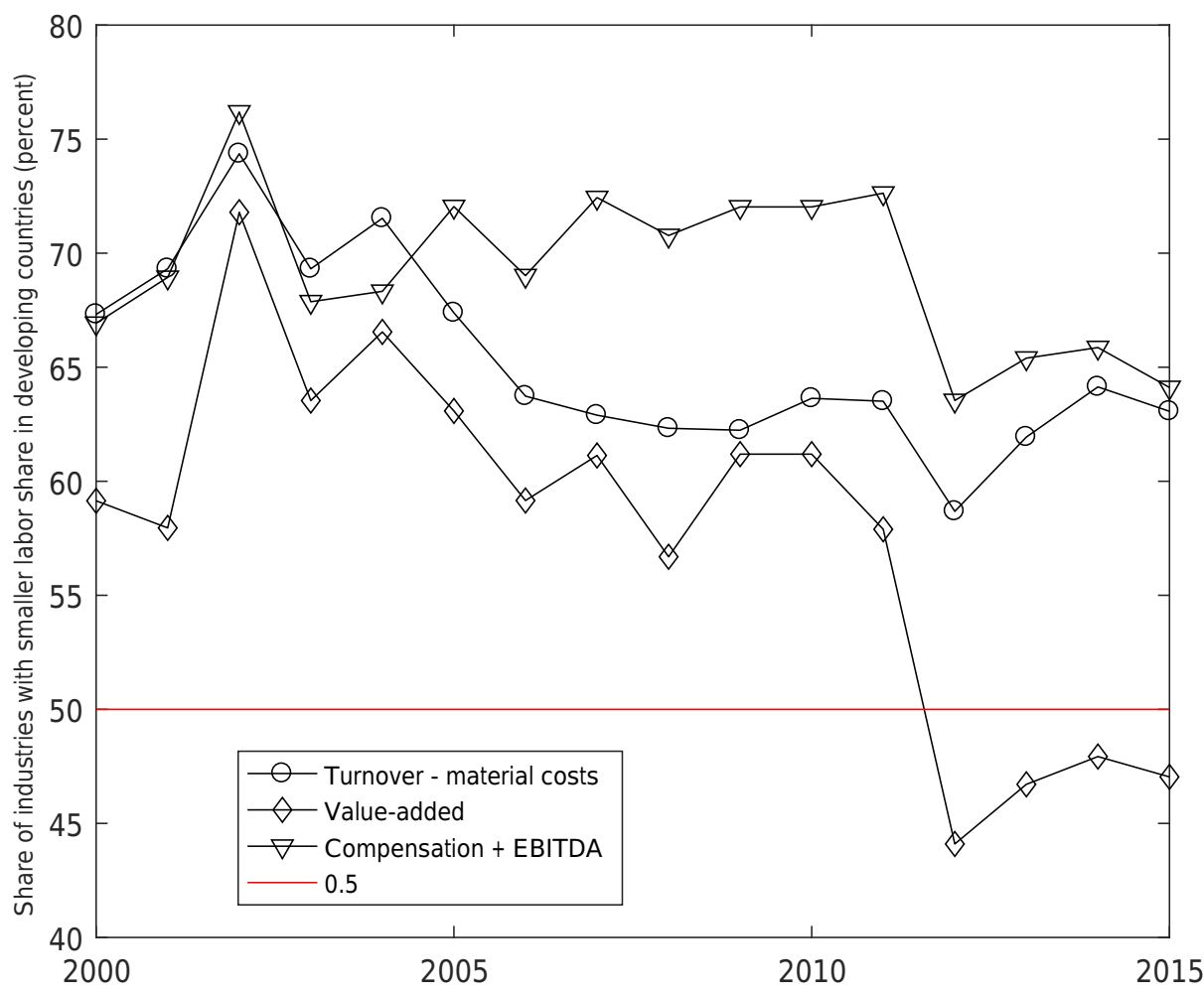

Figure 5: Labor Share in Developing Countries Is Smaller than That in Developed Countries: Share of 4-digit Manufacturing Industries with This Feature

Sources: Orbis; and the author's calculations.

Note: This figure plots the share of NACE Rev. 14 -digit manufacturing industries for which the labor share in developing countries is smaller than that in developed ones as a share of total number. Developed countries are defined as advanced economies defined by the October 2018 IMF World Economic Outlook reports. 


\section{Labor share of goods produced in the north 2. Labor share of goods produced in the south}
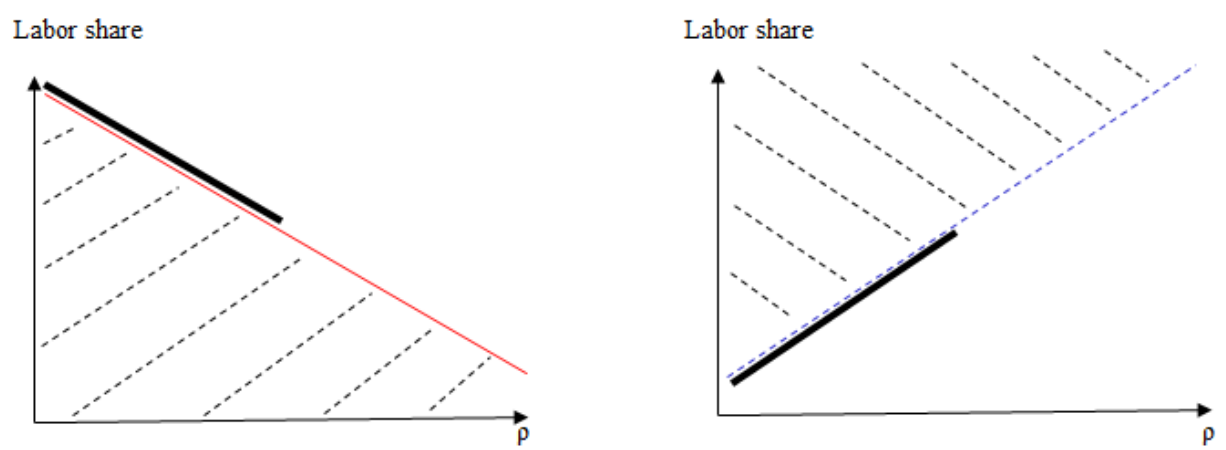

3. Labor share shrinks within offshored goods

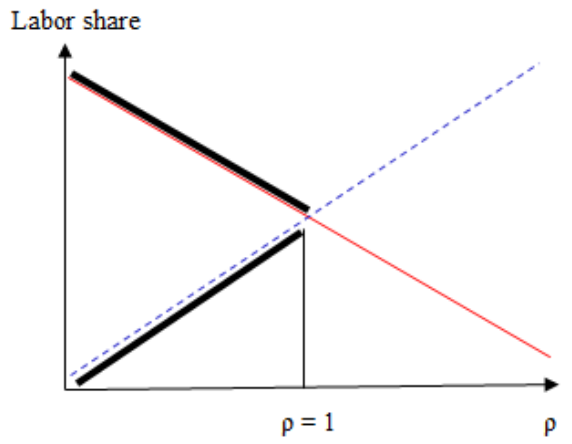

Figure 6: Labor Shares in the North and the South: Illustration of the Model Mechanism

Note: This figure illustrates the model mechanism. Black solid lines indicate cut-off goods for which the elasticity of substitution between capital and labor is smaller than 1 . With such goods being relocated from the north to the south, labor share shrinks within them, causing global labor share to decline. As such goods have largest labor share in the north and smallest labor share in the south, their relocation leads to declines in labor share in both countries. 

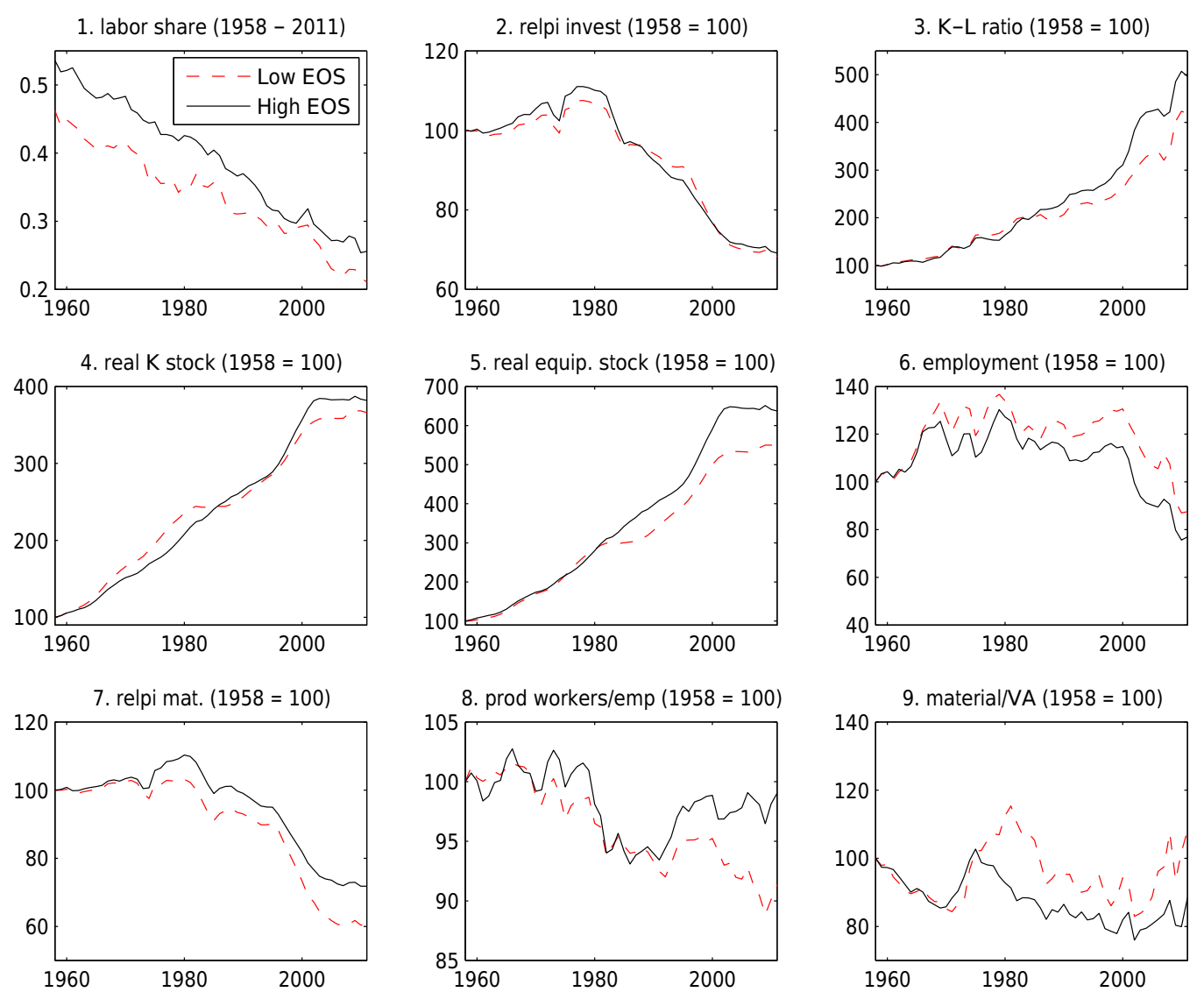

Figure 7: Changes in Factor Shares, Relative Factor Costs and Quantities, and Offshoring Proxies: Manufacturing Industries with High Versus Low Elasticity of Substitution Between Capital and Labor, 1958-2011

Sources: The NBER-CES Manufacturing Database; and the author's calculations.

Note: relpi invest $=$ relative price of investment goods; K-L ratio $=$ the ratio of capital stock to employment; real K stock = real capital stock; real equip. stock = real equipment capital stock; relpi mat. $=$ relative price of materials (excluding energy); prod workers/emp $=$ the ratio of the number of production workers to employment; material/VA = the ratio of material cost (excluding energy) to value-added. Relative prices here are relative to the deflator of private consumption. 

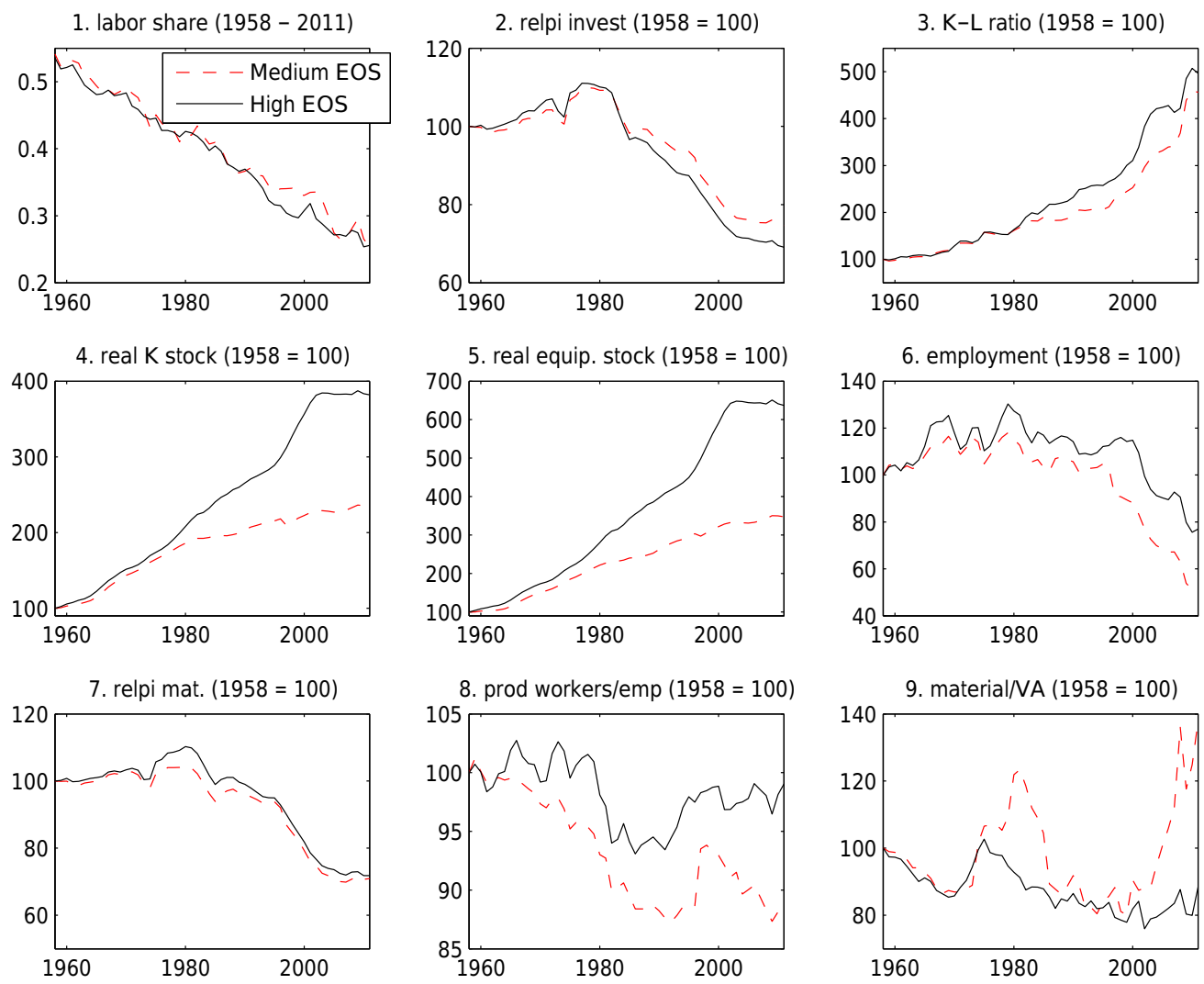

Figure 8: Changes in Factor Shares, Relative Factor Costs and Quantities, and Offshoring Proxies: Manufacturing Industries with High Versus Medium Elasticity of Substitution Between Capital and Labor, 1958-2011

Sources: The NBER-CES Manufacturing Database; and the author's calculations.

Note: relpi invest $=$ relative price of investment goods; K-L ratio $=$ the ratio of capital stock to employment; real K stock = real capital stock; real equip. stock $=$ real equipment capital stock; relpi mat. $=$ relative price of materials (excluding energy); prod workers/emp $=$ the ratio of the number of production workers to employment; material/VA = the ratio of material cost (excluding energy) to value-added. Relative prices here are relative to the deflator of private consumption. 

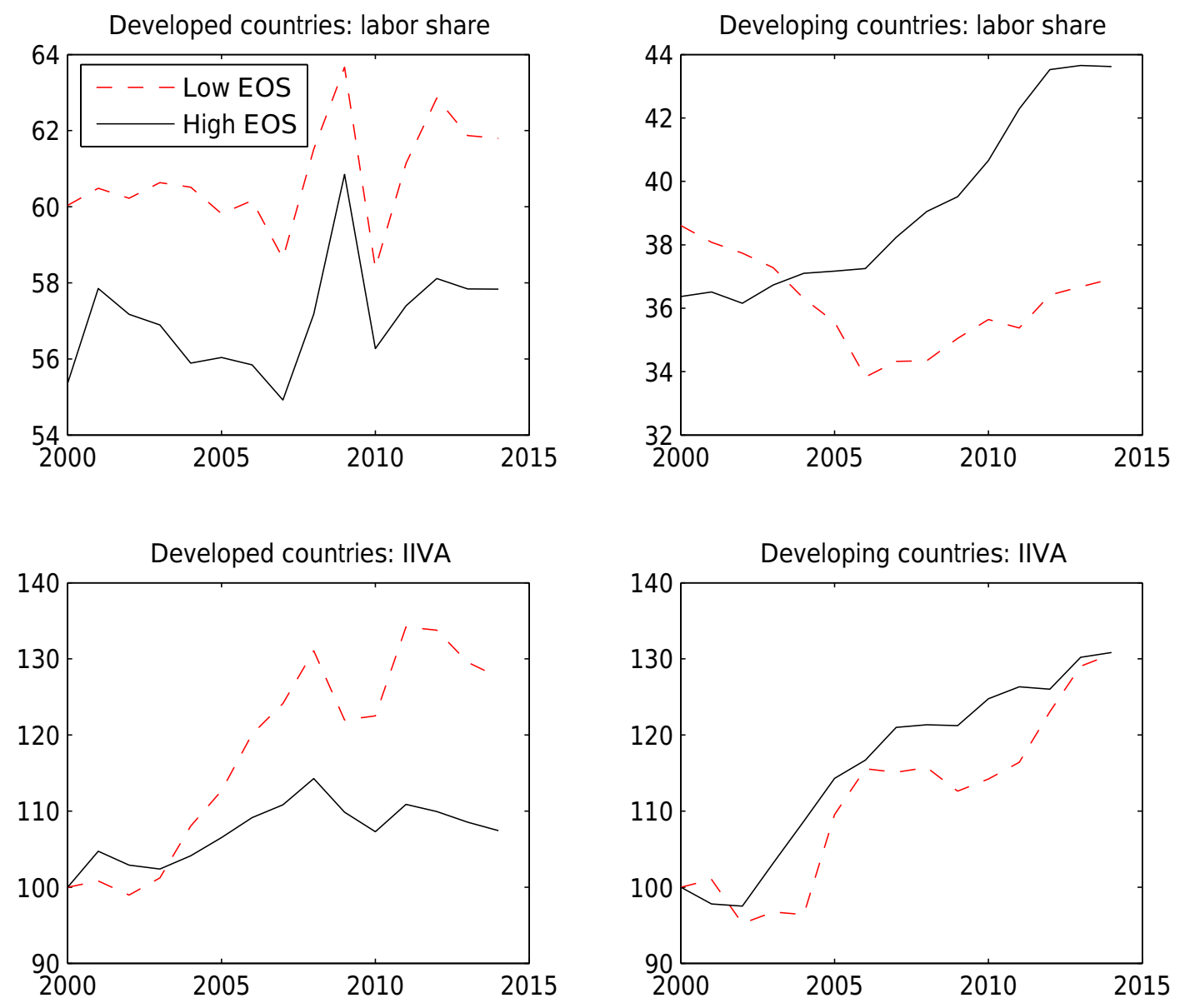

Figure 9: Labor Share and Intermediate Goods Trade in All Countries: Manufacturing Industries with High Versus Low Elasticity of Substitution Between Capital and Labor, 2000-2011

Sources: The World Input-Output database (WIOD); and the author's calculations.

Note: iiva $=$ the ratio of intermediate inputs over value-added. To avoid the results being driven by the United States, the AE group excludes the US. But the pattern is robust to including the United States. 

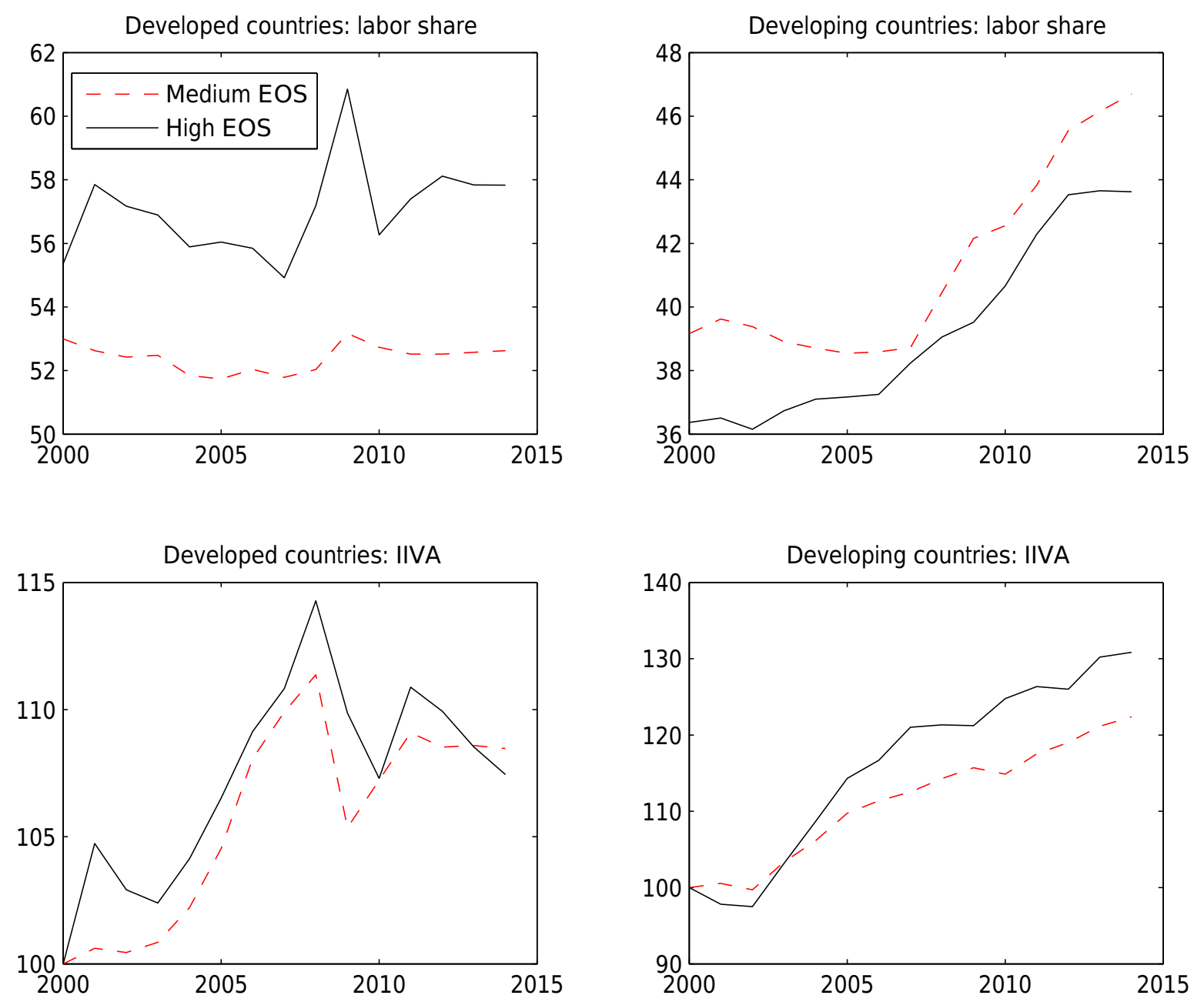

Figure 10: Labor Share and Intermediate Goods Trade in All Countries: Manufacturing Industries with High Versus Medium Elasticity of Substitution Between Capital and Labor, 2000-2011

Sources: The World Input-Output database (WIOD); and the author's calculations.

Note: iiva $=$ the ratio of intermediate inputs over value-added. 

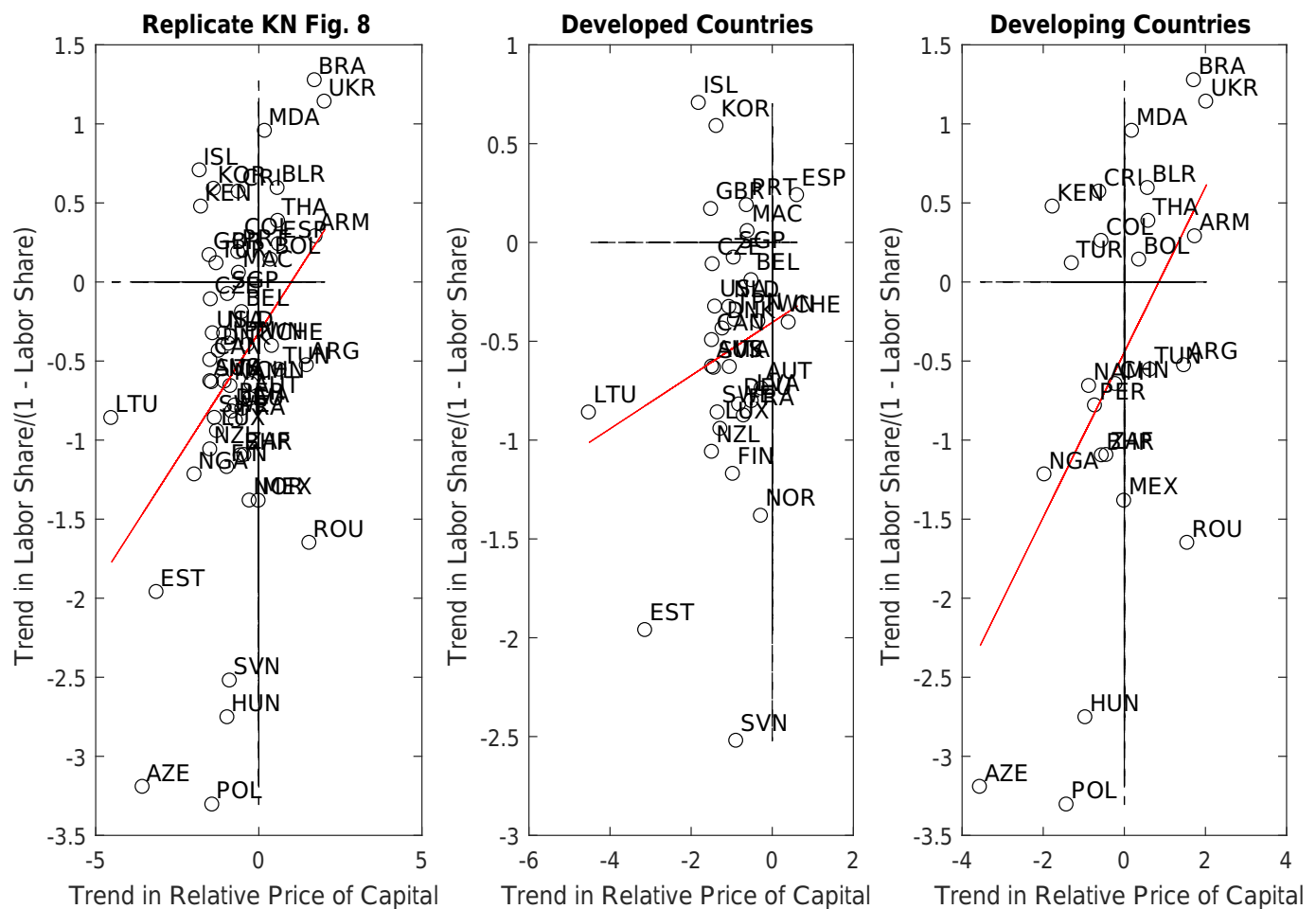

Figure 11: Macroeconomic Elasticity of Substitution Between Capital and Labor by Country Group

Sources: Karabarbounis and Neiman (2013); the KN Labor Share Dataset; and the author's calculations.

Note: This figure replicates Figure 8 of Karabarbounis and Neiman (2013) and suggests that developing countries play a critical role for the macro elasticity of substitution between capital and labor to be large. Developed and developing countries correspond to advanced and emerging market and developing economies defined by October 2018 World Economic Outlook Reports. 


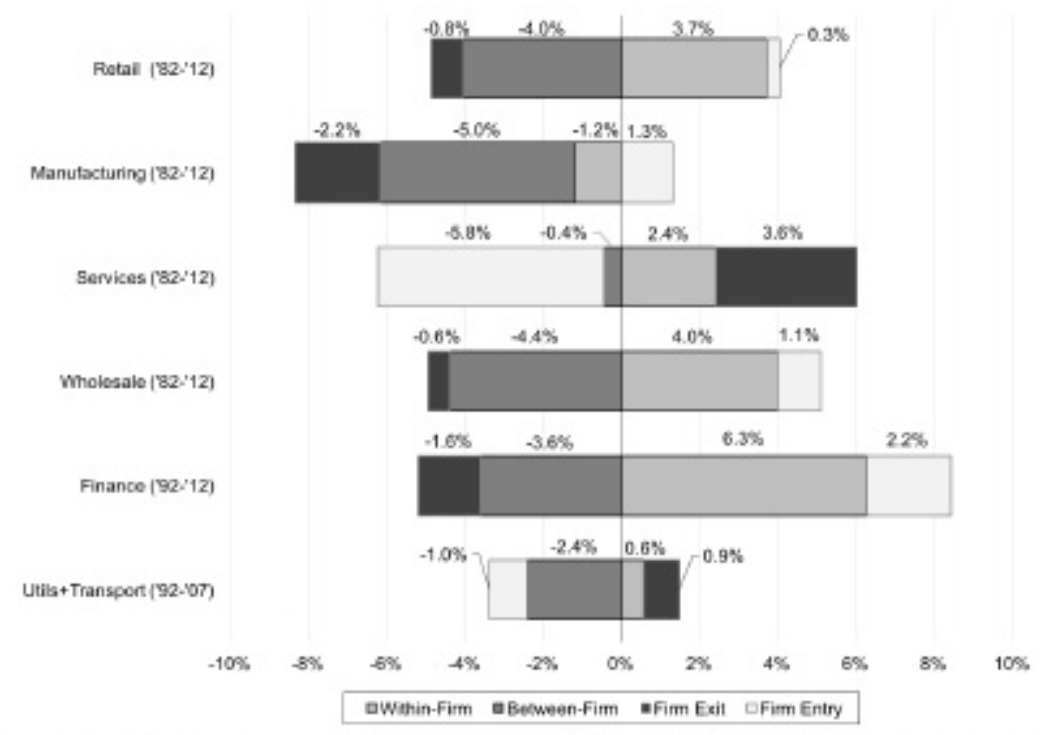

Notes: Each bar represents the cumulated sum of the Melitz-Polanec decomposition components calculated over adjacent five-year intervals. Table 5 reports the underlying year-by-year estimates.

Figure 12: Replication of Figure 10 in Autor et al. (2017): Melitz-Polanec Decomposition of the Change in Labor Share in Six Sectors in the United States

Sources: Autor et al. (2017).

Note: Within-firm effects are positive in all sectors except for manufacturing. 


\section{Appendix}

\section{A.1 Data Sources, Variable Definitions, and Country Grouping}

\section{Data Sources}

The primary data sources for this paper are: the KN Labor Share Database, the World InputOutput database, Orbis, and the World Bank Enterprise Surveys. The first three sources cover the global economy, especially the largest economies. The World Bank Enterprise Surveys focuses on developing countries.

\section{Data Definitions}

Corporate labor share is defined as compensation of employees in the corporate sector divided by corporate gross value added. The KN database provides this variable for individual countries (cls), and the gross corporate value added (cgva).

Payroll labor share in a manufacturing industry is defined as the compensation of employees divided by the value-added of the industry, which is available in the Socio Economic Accounts of the World Input-Output database.

Exports and imports of a manufacturing sector in a country is calculated based on the Input-Output tables of the World Input-output database.

Foreign ownership is defined as the percentage of the firm that is owned by private foreign individuals, companies or organizations, and is available in the World Bank Enterprise Surveys.

Country Sample

The definition of developed and developing countries follows the October 2018 IMF World Economic Outlook's definition for advanced economies and emerging market and developing economies respectively.

The sample countries in the tables and figures are listed in the Appendix Table A.1. As balanced samples are needed to conduct shift-share analyses, and the time coverage is uneven across countries in the KN Labor Share Dataset, I select a sub sample to conduct the analyses in Section II.

\section{A.2 Proof of Propositions}

Proof of Proposition 4 For cut-off goods (i.e. goods for which firms are indifferent about in which country to produce) for which the elasticity of substitution between capital and labor is $\rho$, its labor intensity

$$
\begin{aligned}
\alpha^{\text {cutoff }}(\rho) & =g\left(\rho, \frac{A^{N}}{A^{S}}, w^{N}, w^{S}, R\right) \\
& =\frac{1}{1+\frac{\left(w^{N}\right)^{1-\rho}-\left(\frac{A^{N}}{A^{S}} w^{S}\right)^{1-\rho}}{R^{1-\rho}\left(\left(\frac{A^{N}}{A^{S}}\right)^{1-\rho}-1\right)}} .
\end{aligned}
$$

The labor shares of cut-off goods as a function of the elasticity of substitution between capital 
Appendix Table A.1 Country Samples

\section{A. Country samples in Table 1, Figure 1}

\section{Developed countries/advanced economies}

Austria, Belgium, Cyprus, Czech Republic, Denmark, Estonia, Finland, France, Germany, Italy, Latvia, Lithuania, Luxembourg, Netherlands, Norway, Portugal, Slovakia, Slovenia, Spain, Sweden, Switzerland, United Kingdom, United States

Developing countries/emerging market and developing economies

Armenia, Azerbaijan, Belarus, Bolivia, China, Colombia, Hungary, Kazakhstan, Kyrzgyzstan, Mexico, Micronesia, Moldova, Mongolia, Niger, Poland, Romania, South Africa, Tunisia, Ukraine

\section{B. Country samples in Table 2 and 4, Figure 2, 3 and 4}

\section{Developed countries/advanced economies}

Australia, Austria, Belgium, Canada, Cyprus, Czech Republic, Denmark, Estonia, Finland, France, Germany, Greece, Japan, Korea, Ireland, Italy, Latvia, Lithuania, Luxembourg, Malta, Netherlands, Portugal, Slovakia, Slovenia, Spain, Sweden, Taiwan, United Kingdom, United States

\section{Developing countries/emerging market and developing economies}

Brazil, Bulgaria, China, Hungary, India, Indonesia, Mexico, Poland, Romania, Russia, Turkey

\section{Country samples in Table 5}

Developing countries/emerging market and developing economies Brazil, Bugaria, China, Croatia, Hungary, India, Indonesia, Mexico, Poland, Romania, Russia, Turkey

Note: panel A refers to a balanced sample from the KN dataset in which all countries have labor compensation and gross value-added in the corporate sector available in 1995-2007. Except those in bold, these countries also have the two variables available in 2008-09. Among them, only Armenia, China, Luxembourg, and Romania do not have such information in 2010. Most developing countries would be expcluded from the sample if we require 2011's information. I choose data before 2009 to do the shift-share analyses so that China is included, as excluding China would significantly under-estimate between-country effects. In other panels, the sample selection criteria are the maximum sample available in the data sources. 
and labor if the goods are produced in the north and south are

$$
\begin{aligned}
\omega(\alpha, \rho, N) & =\frac{1}{1+\frac{1-\alpha^{\text {cutoff }}(\rho)}{\alpha^{\text {cutoff }}(\rho)}\left(\frac{R}{w^{N}}\right)^{1-\rho}} \\
& =\frac{1}{1+\frac{1-\left(\frac{A^{N}}{A^{S}} \frac{w^{S}}{w^{N}}\right)^{1-\rho}}{\left(\frac{A^{N}}{A^{S}}\right)^{1-\rho}-1}}, \\
\omega(\alpha, \rho, S) & =\frac{1}{1+\frac{1-\alpha^{\text {cutoff }}(\rho)}{\alpha^{\text {cutoff }}(\rho)}\left(\frac{R}{w^{S}}\right)^{1-\rho}} \\
& =\frac{\left(\frac{A^{N}}{A^{S}}\right)^{1-\rho}-1}{\left(\frac{w^{N}}{w^{S}}\right)^{1-\rho}-1} .
\end{aligned}
$$

To see the monotonic relationship,

$$
\begin{aligned}
\frac{\partial \omega(\alpha, \rho, N)}{\partial \rho} & =-\frac{1}{\left(1+\frac{1-\left(\frac{A^{N} w^{S}}{A^{S}}\right)^{1-\rho}}{\left(\frac{A^{N}}{A^{S}}\right)^{1-\rho}-1}\right)^{2}} \frac{1}{\left(\left(\frac{A^{N}}{A^{S}}\right)^{1-\rho}-1\right)^{2}} \\
& \times\left[\left(\left(\frac{A^{N}}{A^{S}}\right)^{1-\rho}-1\right) \times \ln \left(\frac{A^{N} w^{S}}{A^{S} w^{N}}\right)\left(\frac{A^{N} w^{S}}{A^{S} w^{N}}\right)^{1-\rho}+\ln \left(\frac{A^{N}}{A^{S}}\right)\left(\frac{A^{N}}{A^{S}}\right)^{1-\rho} \times\left(1-\left(\frac{A^{N} w^{S}}{A^{S} w^{N}}\right)^{1-\rho}\right)\right]
\end{aligned}
$$

Define $x=\frac{A^{N}}{A^{S}}, t=\frac{w^{N} A^{S}}{w^{S} A^{N}}$. The second row of the equality above can be expressed as $\left(\frac{1}{t}\right)^{1-\rho} f(x, t)$, with $f(x, t)$ defined as:

$$
f(x, t)=\ln (x)\left((x t)^{1-\rho}-1\right)-\ln (x t)\left(x^{1-\rho}-1\right) .
$$

Then, it is sufficient to show that $f(x, t)>0$ to get $\frac{\partial \omega(\alpha, \rho, N)}{\partial \rho}<0 . f(x, t)>0$ comes from the following properties of $f$ :

$(A 1) \quad f(x, 1)=0$;

(A2) $\quad \frac{\partial f(x, t)}{\partial t}=\frac{1+(1-\rho) \ln (x)(x t)^{1-\rho}-x^{1-\rho}}{t}$, and $\left.\frac{\partial f(x, t)}{\partial t}\right|_{x=1}=0$;

(A3) $\frac{\partial^{2} f(x, t)}{\partial t \partial x}=(1-\rho) x^{-\rho}\left(-1+t^{1-\rho}+t^{1-\rho} \ln (x)(1-\rho)\right)$, which implies $\frac{\partial^{2} f(x, t)}{\partial t \partial x}>0$ if $\quad x>1$ and $t>1$.

To prove $\frac{\partial \omega(\alpha, \rho, S)}{\partial \rho}>0$, I use the same strategy:

$$
\begin{aligned}
\frac{\partial w^{L}}{\partial \rho} & =\frac{1}{\left(\left(\frac{w^{N}}{w^{S}}\right)^{1-\rho}-1\right)^{2}} \\
& \times\left(\left(\frac{A^{N}}{A^{S}}\right)^{1-\rho}-1\right) \ln \left(\frac{w^{N}}{w^{S}}\right)\left(\frac{w^{N}}{w^{S}}\right)^{1-\rho}-\left(\left(\frac{w^{N}}{w^{S}}\right)^{1-\rho}-1\right)\left(\frac{A^{N}}{A^{S}}\right)^{1-\rho} \ln \left(\frac{A^{N}}{A^{S}}\right) \\
& =\frac{1}{\left(\left(\frac{w^{N}}{w^{S}}\right)^{1-\rho}-1\right)^{2}}\left(\frac{w^{N}}{w^{S}}\right)^{1-\rho}\left(\frac{A^{N}}{A^{S}}\right)^{1-\rho}\left[\ln \left(\frac{A^{N}}{A^{S}}\right)\left(\left(\frac{w^{N}}{w^{S}}\right)^{\rho-1}-1\right)-\ln \left(\frac{w^{N}}{w^{S}}\right)\left(\left(\frac{A^{N}}{A^{S}}\right)^{\rho-1}-1\right)\right]
\end{aligned}
$$

Define $z=\frac{A^{N}}{A^{S}}, \mu=\frac{w^{N} A^{S}}{w^{S} A^{N}}$. The term in the bracket of the second row in the equation above 
can be expressed as:

$$
h(z, \mu)=\ln (z)\left((z \mu)^{\rho-1}-1\right)-\ln (z \mu)\left(z^{\rho-1}-1\right) .
$$

To show that $\frac{\partial w^{L}}{\partial \rho}>0$, it suffices to prove that $h(z, \mu)>0$, which comes from the following properties:

(B3) $\frac{\partial^{2} h(z, \mu)}{\partial z \partial \mu}=\frac{(\rho-1) z^{\rho-2}}{\mu}\left(-1+\mu^{\rho-1}+(\rho-1) \mu^{\rho} \ln (z)\right)$, which implies $\frac{\partial^{2} h(z, \mu)}{\partial z \partial \mu}>0$ if $\quad z>1$ and $\mu>1$.

Proof of Proposition 10: Define $M^{i}\left(\frac{w^{i}}{R}, \frac{w^{j}}{R}\right)$ for $i, j \in\{N, S\}$ as:

$$
M^{i}\left(\frac{w^{i}}{R}, \frac{w^{j}}{R}\right)=\ln \left(\int_{(\alpha, \rho) \in \Lambda^{i}} \frac{1}{1+\frac{1-\alpha}{\alpha}\left(\frac{R}{w^{i}}\right)^{1-\rho}} f(\alpha, \rho) d \alpha d \rho\right)-\ln \left(\frac{\frac{w^{i}}{R} L^{i}}{K+\frac{w^{i}}{R} L^{i}+\frac{w^{j}}{R} L^{j}}\right),
$$

$\left(\frac{w^{i}}{R}, \frac{w^{j}}{R}\right)$ solves two labor market conditions:

$$
M^{N}\left(\frac{w^{N}}{R}, \frac{w^{S}}{R}\right)=M^{S}\left(\frac{w^{N}}{R}, \frac{w^{S}}{R}\right)=0
$$

Through algebra, I get:

$$
\begin{aligned}
\left.\frac{M^{i}}{\frac{w^{i}}{R}}\right|_{M^{i}=0} & =\frac{K+\frac{w^{i}}{R} L^{i}+\frac{w^{j}}{R} L^{j}}{\frac{w^{i}}{R} L^{i}}\left(\frac{\partial h\left(\frac{w^{i}}{R}, \alpha, \rho\right)}{\partial \ln \left(\frac{w^{i}}{R}\right)}+\epsilon_{i}\right)-1-\phi^{i} \\
& +\frac{\partial \ln \left(K+\frac{w^{L}}{R} L^{L}+\frac{w^{H}}{R} L^{H}\right)}{\partial \ln \left(\frac{w^{i}}{R}\right)} \\
\left.\frac{M^{i}}{\frac{w^{j}}{R}}\right|_{M^{i}=0}= & \frac{K+\frac{w^{i}}{R} L^{i}+\frac{w^{j}}{R} L^{j}}{\frac{w^{i}}{R} L^{i}} \frac{\partial h\left(\frac{w^{i}}{R}, \alpha, \rho\right)}{\partial \ln \left(\frac{w^{j}}{R}\right)},
\end{aligned}
$$

where

$$
\begin{aligned}
\frac{\partial h\left(\frac{w^{i}}{R}, \alpha, \rho\right)}{\partial \ln \left(\frac{w^{k}}{R}\right)} & =\int_{\rho \in(0,+\infty)} f\left(g\left(\rho ; \frac{A^{N}}{A^{S}} ; w^{N}, w^{S}, R\right)\right) \omega(\alpha, \rho, i) \frac{g\left(\rho ; \frac{A^{N}}{A^{S}} ; w^{N}, w^{S}, R\right)}{\partial \ln \left(\frac{w^{k}}{R}\right)} \delta^{i} d \rho, \\
\text { with } \quad \delta^{N}=1 \text { and } \delta^{S}=1 . & \frac{\partial\left(\frac{1}{1+\frac{\alpha}{1-\alpha}\left(\frac{R}{w^{i}}\right)^{1-\rho}}\right)}{\partial \ln \left(\frac{w^{i}}{R}\right)} f(\alpha, \rho) d \alpha d \rho .
\end{aligned}
$$

I next show that if $\phi^{N}$ and $\phi^{S}$ are sufficiently large, the following inequality holds:

$$
\left.\frac{d \ln \left(\frac{w^{N}}{R}\right)}{d \ln \left(\frac{w^{L}}{R}\right)}\right|_{M^{S}=0}>\left.\frac{d \ln \left(\frac{w^{N}}{R}\right)}{d \ln \left(\frac{w^{H}}{R}\right)}\right|_{M^{S}=0} .
$$


The inequality can be expressed as:

$$
\begin{aligned}
\left.\frac{d \ln \left(\frac{w^{N}}{R}\right)}{d \ln \left(\frac{w^{L}}{R}\right)}\right|_{M^{S}=0} & =\left(1+\phi^{N}-\frac{K+\frac{w^{N}}{R} L^{N}+\frac{w^{S}}{R} L^{S}}{\frac{w^{N}}{R} L^{N}}\right. \\
& \left.\times\left(\epsilon_{N}+\frac{\partial h\left(\frac{w^{N}}{R}, \alpha, \rho\right)}{\left.\partial \ln \left(\frac{w^{N}}{R}\right)\right)}\right)-\frac{\partial \ln \left(K+\frac{w^{S}}{R} L^{S}+\frac{w^{N}}{R} L^{N}\right)}{\ln \left(\frac{w^{N}}{R}\right)}\right) \\
& \times\left(1+\phi^{S}-\frac{K+\frac{w^{N}}{R} L^{N}+\frac{w^{S}}{R} L^{S}}{\frac{w^{S}}{R} L^{S}}\right. \\
\times & \left(\epsilon_{S}+\frac{\partial h\left(\frac{w^{S}}{R}, \alpha, \rho\right)}{\left.\partial \ln \left(\frac{w^{S}}{R}\right)\right)}-\frac{\partial \ln \left(K+\frac{w^{S}}{R} L^{S}+\frac{w^{N}}{R} L^{N}\right)}{\ln \left(\frac{w^{S}}{R}\right)}\right) \\
> & \left(\frac{K+\frac{w^{N}}{R} L^{N}+\frac{w^{S}}{R} L^{S}}{\frac{w^{N}}{R} L^{N}} \times \frac{\partial h\left(\frac{w^{N}}{R}, \alpha, \rho\right)}{\partial \ln \left(\frac{w^{S}}{R}\right)}\right. \\
+ & \frac{\partial \ln \left(K+\frac{w^{S}}{R} L^{S}+\frac{w^{N}}{R} L^{N}\right)}{\partial \ln \left(\frac{w^{S}}{R}\right)} \times\left(\frac{K+\frac{w^{N}}{R} L^{N}+\frac{w^{S}}{R} L^{S}}{\frac{w^{S}}{R} L^{S}} \times \frac{\partial h\left(\frac{w^{S}}{R}, \alpha, \rho\right)}{\partial \ln \left(\frac{w^{N}}{R}\right)}\right. \\
& \left.+\frac{\partial \ln \left(K+\frac{w^{S}}{R} L^{S}+\frac{w^{N}}{R} L^{N}\right)}{\partial \ln \left(\frac{w^{N}}{R}\right)}\right) \\
& =\left.\frac{\operatorname{dln}\left(\frac{w^{N}}{R}\right)}{\operatorname{dln}\left(\frac{w^{H}}{R}\right)}\right|_{M^{S}=0} \cdot
\end{aligned}
$$

It is straightforward to verify that this inequality holds if $\phi^{N}$ and $\phi^{S}$ are sufficiently large. 